\title{
Recent Innovations in Peptide Based Targeted Drug Delivery to Cancer Cells
}

\author{
Yosi Gilad ${ }^{1,2}$, Michael Firer ${ }^{2}$ and Gary Gellerman ${ }^{1, *}$ \\ 1 Department of Chemical Sciences, Ariel University, Ariel 40700, Israel; yosig@ariel.ac.il \\ 2 Department of Chemical Engineering and Biotechnology, Ariel University, Ariel 40700, Israel; firer@ariel.ac.il \\ * Correspondence: garyg@ariel.ac.il; Tel.: +972-3-9066442 \\ Academic Editor: Kenneth Cornetta \\ Received: 21 April 2016; Accepted: 23 May 2016; Published: 26 May 2016
}

\begin{abstract}
Targeted delivery of chemotherapeutics and diagnostic agents conjugated to carrier ligands has made significant progress in recent years, both in regards to the structural design of the conjugates and their biological effectiveness. The goal of targeting specific cell surface receptors through structural compatibility has encouraged the use of peptides as highly specific carriers as short peptides are usually non-antigenic, are structurally simple and synthetically diverse. Recent years have seen many developments in the field of peptide based drug conjugates (PDCs), particularly for cancer therapy, as their use aims to bypass off-target side-effects, reducing the morbidity common to conventional chemotherapy. However, no PDCs have as yet obtained regulatory approval. In this review, we describe the evolution of the peptide-based strategy for targeted delivery of chemotherapeutics and discuss recent innovations in the arena that should lead in the near future to their clinical application.
\end{abstract}

Keywords: targeted drug delivery; therapeutic carriers; peptide-drug conjugates; cancer therapy; cancer imaging

\section{Introduction}

Selective delivery of chemotherapeutics to cancer cells has challenged modern chemotherapy from its very beginning. Achieving maximized therapeutic effect as well as minimal off-target side effects requires not only the development of effective strategies for targeted delivery of anti-cancer agents, but also restricted release of the drug payload to the tumor cell or at least its local environment. The strategy of Targeted Drug Delivery (TDD) to tumor tissues is based on the idea that despite the overall molecular similarity between cancer and normal cells, there remains would sufficient cellular heterogeneity to distinguish normal cells from cancer cells. One of the typical biological consequences of cancer is the over expression or unique expression of certain cell surface receptors. These "biomarkers" are often receptors whose activation can lead to enhanced proliferation, migration and invasion of cancer cells and tumor angiogenesis, which are all essential for tumor progression. Selective targeting of these receptors by high affinity biomolecular carriers can mitigate the selectivity problems of chemotherapy [1,2]. Several types of ligands have been tested as potential drug carriers, the most celebrated of which are antibodies [3]. However, there remain a number of pitfalls to their use [3]. In this review, we summarize the strategies, biological activity, challenges and future perspectives of peptide drug conjugates (PDCs) in the targeted treatment of cancer (Figure 1). 


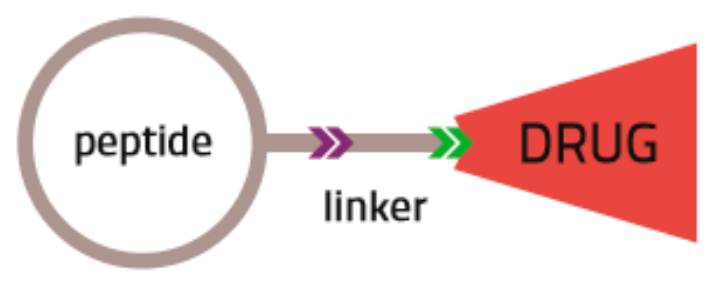

Figure 1. Schematic representation of PDC (peptide based drug conjugate).

\section{Strategies for Cancer Cell Targeting Peptides Discovery}

\subsection{Phage Display}

In 1985, Smith showed that filamentous bacteriophages (bf) can be genetically engineered to express foreign peptide sequences on their surface (protein coat) [4]. This led to the development of libraries of phages in which each clone displays a peptide of combinatorial sequence $[5,6]$. These libraries can be used in vitro to screen for and isolate clones displaying peptides with high selectivity for almost any desired target. They can also be injected into an animal to isolate clones that bind to a desired target tissue [7]. Multiple repetitions on these selection and amplification steps, termed panning, bring about enrichment of the clones with highest affinity to a specific target.

In the literature, there are two approaches to isolating target specific clones; one approach is to expose the total phage pool to the target, for example, an antibody. The binding clones are then recovered and exposed to a non-relevant protein, such as a non-relevant antibody in order to recover only those clones specific to the target antibody's paratope. The alternate approach proposes that the original phage pool contains mostly non-specific clones that indeed may compete or interfere with the binding of specific clones to the target. Therefore, in this approach, the phage pool is first exposed to one or several non-specific targets and non-binding clones are recovered. These clones are then exposed to the desired target and specific binders isolated.

Since being introduced by Smith [4], this technology_known today as phage display peptide libraries - has become a powerful tool for the discovery of specific ligands $[6,8]$ with high receptor affinity $[6,9]$.

Notwithstanding the contribution of phage-display to the discovery of targeting peptides the technique has some critical disadvantages. One of these relates to the method of recovery of phage positive clones. Traditionally, recovered phage are titrated on bacterial lawns, however it is technically challenging to retrieve and sequence the peptide inserts of more than 10-20 such clones. Thus, many potentially interesting clones are missed. The introduction of Next Generation Sequencing (NGS) can now alleviate this problem [10]. While NGS is more expensive and time consuming, it allows analysis of the entire pool of target positive phage. Another disadvantage is that the technology has limited, in that it produces peptides with predetermined length and only from natural amino acids. These disadvantages can be overcome using synthetic combinatorial methods, which are described below.

\subsection{Synthetic Peptide Libraries-OBOC}

In 1984, Geysen et al. [11] introduced a combinatorial approach for the segmental epitope mapping of the VP1 protein from the foot and mouth disease virus. A library of 208 overlapping hexapeptides, each peptide differing at one amino acid position, was synthesized, covering the whole 213 amino acid sequence of the protein. The peptide library was synthesized on a solid support, enabling its rapid and feasible immunological screening [11]. In its original form this combinatorial method, later termed "multipin technology", utilized polyethylene pins covered with acrylic acid (for the formation of a polar support with improved solubility in polar solvents) as a solid support. These pins were adapted to a 96 well polypropylene plate, where each well served as a separate reaction vessel. At the end of the synthesis the peptides are directly subjected to a biological screening or are first removed from the pins 
by enzymatic [12] or chemical [13] cleavage. Several different combinatorial methods and techniques have since been introduced [14-16], and the field of synthetic peptide libraries has now become a powerful tool for drug discovery [17-19] as well as for fundamental biological investigation [20,21]. In the context of synthetic homing peptides, the one-bead-one-compound (OBOC) method has made a particular impact [22].

The OBOC method is based on a "mix and split" technique and enables preparation of peptide libraries with $10^{6}-10^{8}$ different peptides [23]. The peptides are coated on to $100 \mu \mathrm{m}$ diameter polymeric beads, each bead covered with about $10^{13}$ copies of the same peptide [15]. The library can be screened against various biological targets, including intact cells or specific receptors. Beads, which physically bind to the target of interest, are isolated and the structure of the coating compound can then be elucidated $[15,24]$. Recently a novel screening method for identification of targeting peptides derived from a "mix and split" library was reported [25]. This method involves encoding of each member of the library with a unique peptide nucleic acid (PNA) [26,27] which is biologically stable [28], yet suitable for DNA microarray assays $[29,30]$. PNA encoded peptide libraries are appropriate for the identification of targeting peptides to any biological target of interest, either in vitro or in vivo due to the stability of the PNAs in biological environments.

The synthetic flexibility of the OBOC method, and the size of its libraries make it an ideal optimization tool for peptide leads previously discovered by phage display or any other methodology [23].

\subsection{SPOT-Synthesis}

In 1992, Frank introduced a method using cellulose membranes as the solid support for peptide synthesis [31]. In the SPOT synthesis, the peptides are synthesized on pre-functionalized cellulose, which enables the attachment of activated amino acids. "Spotting" small volumes of reagents at defined positions on the cellulose support actually results in a creation of microreactors, whose size is defined by the volumes dispensed and the physical properties of the solid support. The scale of the reaction, as well as the number of synthesized peptides are directly derived both from the size of separate spots on the membrane sheet. Removal of the protecting groups and washings are performed by dipping the sheet in the appropriate solution. After the accomplishment of the synthetic procedure, the peptides can be assayed while attached to the solid support, or can be cleaved for further performance of bioassays in solution. The advantages of SPOT synthesis are that it is a flexible, simple and cheap method, it yields sufficient amounts of product [32], and can be applicable for various biological [33,34] and synthetic [35-37] applications. Since the invention of this parallel synthetic technology, it has been developed further by several groups, including the introduction of new polymeric solid supports [38-40], linker anchors [35,41,42] and automated systems [42,43].

In contrast to biological combinatorial method such as phage display, synthetic combinatorial methods have the advantage that they can incorporate D-amino acids, unnatural amino acids and non-amino acid building units into the combinatorial sequence [22]. The increased stability of these types of compounds in the proteolytic environment of biological fluids-compared to natural L-amino acids - enhances the half-life of the targeting ligand and can contribute to increased efficacy of the TDD system [44-46].

\subsection{Rationally Designed Peptides}

Multistep syntheses and the need for exhausting screening of random combinatorial peptide libraries consisting of millions of different compounds are motivating the design of more target oriented peptide libraries. Rational design of peptide ligands generally depends on bioinformatic databases and a resolved crystallographic structure of the target-ligand complex together with computational methods, in order to design more appropriate binding compounds [47].

One sophisticated approach is based on homology modeling. In this approach the design of new ligands to target is performed by using known targets as structural templates. As we have 
recently described, the ligand interactions with the different targets can be studied by a stepwise energy evaluation in which the effects of ligand mutations and different residues of the target are examined [48,49]. Such an approach provides a valuable alternative to a costly and time-consuming combinatorial approach since it can dramatically decrease the number of candidate peptides to be synthesized and tested.

Rational design of peptides is usually validated by two optimization methodologies: cyclo scanning (CYCLOSCAN) and positional scanning. These methods are also useful in phage display and OBOC for optimizing peptide hits. Notably, classical modes of cyclization include the formation of a lactam bridge through carboxyl and amino functional groups, or disulfide bridges through thiol groups leading to side-chain-to-side-chain bridge formation (Figure 2). Two main drawbacks to this classical mode were reported: (i) cyclization may lead to a loss of biological activity, due to the involvement of side chain groups crucial for bioactivity; and (ii) the number of cyclization possibilities is limited. If the linear peptide does not contain the appropriate amino acid to allow classical cyclization, various amino acids in the native sequence need be replaced by amino acids bearing amine (Lys, Orn), carboxyl (Glu, Asp) or thiol (cysteine), an operation that may lead to loss of biological activity [50,51].

Side-to-side chain cyclization

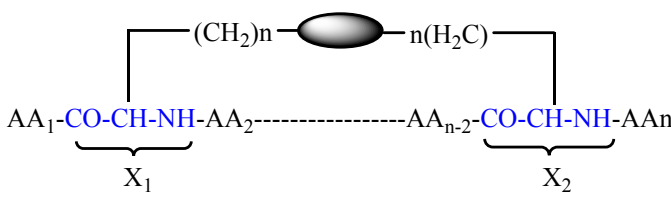

$\mathrm{X}_{1,2}=\mathrm{Lys}$, Orn, Gly, Asp, Cys, HCys
Backbone cyclization

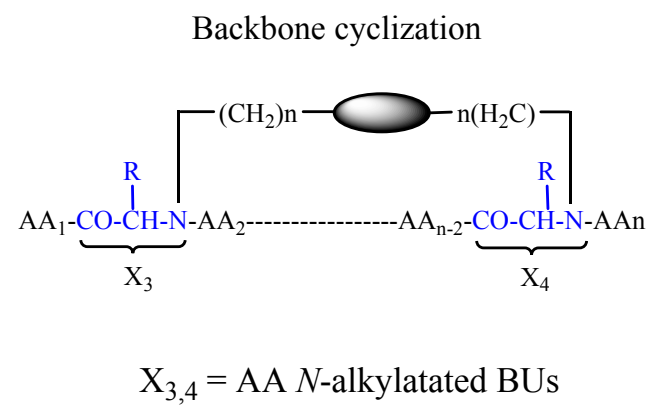

$\mathrm{X}_{3,4}=\mathrm{AA} N$-alkylatated BUs

Figure 2. Schematic representation of peptide optimization methodologies.

To overcome these pitfalls, Gilon et al., applied a new facile approach of backbone cyclization in which any two backbone nitrogens are connected through bridges of various sizes and chemical nature [52-55]. In this method, side-chains are not altered, and a highly variable and large set of different cyclizations can be applied to any linear sequence [56]. Thus, one can generate conformational libraries in which many diverse amino acid sequences share the same structure, thereby enabling the optimization of a known three-dimensional biological motif, or libraries in which a single sequence is contained within a large variety of conformations, thereby identifying the active conformation of a biologically active sequence.

Positional scanning for peptide sequence begins with identification of an amino acid of interest at a single position, followed by sequential substitution with other amino acids. Increased bioactivity of the peptide indicates the preferred amino acids at altered positions in the sequence [57,58].

\section{Targeted Delivery of Chemotherapeutics Based on Clinically Investigated Peptides: Arginine- Glycine-Aspartic Acid (RGD), Somatostatin, Luteinizing Hormone-Releasing Hormone (LHRH) and Bombesin}

The success of using peptides to target over or exclusively expressed receptors in cancer cells, including those that are associated with tumor angiogenesis, serves as a basis for the creation of targeted drug delivery (TDD) systems. These systems are generally constructed with a peptide as a targeting moiety, a linker moiety and a therapeutic agent, as schematically presented in Figure 1. While a number of targeting peptides clinical applications have been isolated and are being developed), the tripeptidic sequences-RGD—have received significant attention. 


\section{1. $R G D$}

In their pioneering work in the mid-1980s, Ruoslahti and Pierschbacher reported on the importance of the Arginine-Glycine-Aspartic acid (RGD) tri-sequence in fibronectin as an essential cell recognition site for integrin $\alpha_{5} \beta_{1}$ [59]. This observation has rapidly led to other evidence for the central role of RGD as a general ligand for additional proteins [60-65].

In parallel, a family of glycoprotein cell surface receptors was discovered that were recognized by the RGD sequence, [66-72]. This class of cell surface receptors, consisting of two subunits in mammalian cells $[73,74]$, were for the first time termed "Integrins" in 1986 for their role as "an integral membrane complex involved in the transmembrane association between the extracellular matrix and the cytoskeleton" [75].

Since integrins are involved in processes which are usually associated with tumor progression such as angiogenesis, invasion and metastasis, and since the RGD peptidic ligand selectively targets them, integrins have attracted special focus. Currently, 24 distinct integrins are known [76] and they have been shown to play key roles in many processes including cell adhesion, migration, and proliferation [77]. Enhanced expression of specific integrins in cancer cells is crucial for promoting metastasis [78-80], angiogenesis [81], proliferation [82,83], migration [84-86] and invasion [87,88], as well as for the proteolytic destruction of extra cellular matrix (ECM) [87], all essential components in the process of tumor progression [89]. The variety of essential functions attributed to the different members of this receptor family in the neoplastic process have been comprehensively reviewed $[89,90]$. The over expression of integrins and their important role in different cancers, make them an obvious target for therapeutic intervention [91,92], as well as for the selective delivery of chemotherapeutics [93-96], nanoparticles [97], and imaging agents [98,99]. RGD has for several reasons often been selected as an attractive targeting ligand in many peptide-drug conjugates: it is recognized by 8-12 of the 24 known integrins [93], and there is confirmation of the recognition of RGD by integrins on the structural basis [100], which is also supported by the crystal structure of $\alpha_{\mathrm{v}} \beta_{3}$ integrin with the RGD analog Celingetide [101]. For example, Ruoslahti et al published a work in which RGD peptides were used to selectively deliver cytotoxic compounds to cancer cells. The researchers showed that doxorubicin covalently conjugated to the nonapeptide CDCRGDCFC considerably improved survival rates of mice bearing human MDA-MB-435 breast carcinomas [94]. In another paper, Sherz and coworkers reported on selective accumulation of the cyclic RGD analog conjugated to the fluorescent bacteriochlorophyll analog in the tumor necrotic domain in MDA-MB-231-RFP bearing mice, allowing early detection of tumor proliferation [102]. Conjugation of highly potent microtubulin poison paclitaxel to the bicyclic RGD peptide $\mathrm{Ec}(\mathrm{RGDyK})_{2}$ resulted in increased drug efficacy towards tumor cells and decrease in off-target toxicity [96].

Other highly effective RGD analogs include 9-RGD [103], iRGD [104], and the cyclic penta-peptide Cilengitide, the latter being developed by Kessler and co-workers $[105,106]$. Cilengitide has reached phase III clinical trials for the treatment of glioblastoma [107] and phase II clinical trials for some other tumors [92]. In all these cases Cilengitide acts as a highly specific antagonist of $\alpha_{\mathrm{v}} \beta_{3}$ and $\alpha_{v} \beta_{5}$ integrins [92,101,107], which are found to be over-expressed integrins in many cancerous cells. To enable conjugation of imaging and therapeutic payloads to Cilengitide, functionally adopted derivatives had been designed [108]. Recently, we reported the synthesis of three novel peptide-drug conjugates based on the cyclic $(\operatorname{RGDf}(N \mathrm{Me}) \mathrm{V})$ penta-peptide in which the methylated valine was mutated to either Lys or Ser enabling primary amine or hydroxy group as a site for drug conjugation [109]. The chemotherapeutic drugs Chlorambucil (CLB) and Camptothecin (CPT) were conjugated to the peptide carrier through amide, ester (for CLB) and carbamate (for CPT) bonds (Table 1). In that report, we provided computational evidence that the conjugation of drug moieties to the backbone of the parent peptide does not significantly alter its conformational space. Thus all conjugates are expected to adopt solution conformations similar to the bio-active conformation of the parent peptide as observed in its complex with the integrin (PDB code 1L5G) [101]. The importance of keeping the correct conformation of the peptide backbone core to maintain binding affinity and 
receptor specificity was also discussed [92,110,111]. In another report, we described the design and synthesis of four $(\mathrm{RGDf}(\mathrm{NMe}) \mathrm{V})$ based conjugates with dual drug payload, which resulted in enhanced cytotoxic effect towards cancer cells in comparison with mono-loaded counterparts [112]. A similar effect of increased cytotoxicity as a result of multi-loading of the carrier was also observed with a non-RGD peptide-based ligand. In this case, increased loading of the MPB peptide with the alkylating agent CLB resulted in selective enhanced cytotoxicity towards leukemic cells [113].

\section{2. $L H R H$}

Over expression of luteinizing hormone releasing hormone (LHRH) receptors in hormone-associated cancers makes it another attractive target for a selective delivery of chemotherapeutics. In the mid-1980s, analogs of LHRH peptide were introduced to target LHRH receptor in prostate [114] and breast [115] cancers. Since then this class of peptides has been extensively tested as carriers of chemotherapeutic agents to cancer cells. For example, LHRH analogs were conjugated to doxorubicin (DOX) (conjugate AN-152) or its counterpart 2-pyrollino-DOX (conjugate AN-207), resulting in targeted therapeutic conjugates in various cancer models [116-128]. In AN-152, the $\alpha$-keto hydroxyl group on ring A of Dox is linked through an ester glutarate on Lys in position 5 of LHRH. AN-152 (currently named AEZS-108) has reached clinical trials [129-131]. Conjugation of LHRH analogs with other toxic agents, such as membrane disrupting peptide [132], toxins [133] and PEGylated delivery systems containing the apoptotic agent camptothecin [134,135], for targeted therapy of cancer cells, were prepared and tested as well (Table 2).

\subsection{Somatostatin}

Somatostatins are a five-membered family [136] of transmembrane G-protein coupled cell-surface receptors widely distributed in a variety of tumors [137-142], which also makes them an attractive target for selective delivery of chemotherapeutics. While the native somatostatin peptide has high affinity to all five receptor subtypes, its very short in vivo half-life limits its utility as a targeting agent [46]. However, several effective analogs of this peptide have been developed, including two FDA approved and clinically applied radiolabeled conjugates-Octreoscan [143-145] and Depreotide $[146,147]$. Apart from radiolabeled conjugates of somatostatin analogs, several drug conjugates for targeted delivery were reported as well [148]. For example a CPT-somatostatin conjugate, which was developed by Coy and coworkers by directly coupling CPT to the N-terminus of the targeting peptide, showed potent inhibitory activity against various human tumors in vivo [149-151]. Paclitaxel (PXT) (which interferes with the normal breakdown of microtubules during cell division) was conjugated to the N-terminal of the SST analog octreotide, which resulted in selective activity of PTX towards breast cancer cells MCF-7 [152]. DOX-SST conjugate (AN-238) [153] displayed significant antitumor activity against various cancers including ovarian, prostate, pancreatic, melanoma, lymphoma and glioblastoma [2,154]. Importantly, AN-238 was also able to overcome multidrug resistance induced by conventional chemotherapy [155]. Despite the abundance of reported drug-peptide conjugates in TDD applications, in our opinion the chemistry of carrier-drug attachment has not received enough attention. Characteristics like linker attachment sites that retain carrier activity, linker length and composition, and the design of drug analogs for attachment to the linker are crucial for securing successful drug delivery [156-160]. Redko and co-workers described the synthesis of five novel peptide-drug conjugates based on the disulfide bridged backbone cyclic somatostatin peptide analog 3207-86 which is SSTR2 selective inhibitor [161]. Five chemotherapeutic molecules, acting through different oncogenic mechanisms, were linked to the core peptide carrier, yielding SST-drug conjugates (Table 3). In that work chemo- and biostability of the peptide drug conjugates in various media were measured, representing release profiles for each drug. This information is useful for further optimization of drug release capabilities from 3207-86 peptide-drug conjugates. The 3207-86 cyclic somatostatin peptide was developed by Kostenich et al. [162]. In addition, these conjugates were found to be specifically cytotoxic to the cancer cell lines that overexpressed SSTR2, such as HCT 116 
human colon adenocarcinoma, H1299 human non-small-cell lung carcinoma and TRAMP C2 human prostate cancer cell lines as oppose to the free drug.

\subsection{Bombesin}

Mammalian Bombesins $(\mathrm{BN})$ are a family of growth receptors (gastrin-releasing peptide receptors (GRPR), neuromedin B receptor (NMBR) and Bombesin receptor subtype 3 (BRS3)) which are frequently overexpressed by a number of common cancers such as prostate, breast, lung, gastric, malignant gliomas and colon [163]. The human GRP, as well as mammalian bombesin-BN receptor ligands are brain-gut peptides-plays an important role in cancer [164,165]. It has been observed that various types of cancers can also synthesize bombesin and GRP [166]. The autocrine mode of action of these peptides brings about stimulation of the growth of the tumor that produces them via bombesin receptors expressed on their surfaces $[165,167]$. Consequently, BN receptors are interesting targets for TDD to cancer cells. Development of various CPT-BN conjugates has led to the discovery of a potent BN agonist drug conjugate (CTP-L2-BA3) that is cytotoxic for cells overexpressing all mammalian BN receptor subtypes [168]. With the aim of improving the targeting efficacy of the BN-drug conjugate, a multi-ligand approach, whereby paclitaxel (PTX) is conjugated to a divalent BN analog BBN carrier was prepared, resulting in a product with enhanced cytotoxicity [169]. Another BN conjugate was prepared with DOX as a toxic payload [170]. Additionally, cytotoxic conjugates of BN peptides have been prepared by loading them with marine toxins [171], mitochondria-disruptive peptides [172], radiolabeled agents $[173,174]$ and others [175] (Table 4).

\subsection{Angiopeptin-2}

Receptor-mediated transcytosis expedites BBB (Blood-Brain-Barrier) crossing of various macromolecules after initial binding of a targeting molecule to a receptor expressed on brain endothelial cells [176]. Low-density lipoprotein receptor (LDLr) is targeted by angiopeptin-2, defining it as a specific "gate" for delivery of payloads to brain malignancies. The most promising PDC based on this peptide ligand is 19-amino-acid linear angiopeptin-2-paclitaxol PDC (ANG1005) that targets LDLr-1 over expressed on solid tumor [177] and is associated with enhanced transcytosis across the Blood-Brain-Barrier (BBB) [178].

ANG1005 is composed of three molecules of Paclitaxel connected to the two Lys at positions 5 and 9, and to the N-terminal Thr (Table 4). ANG1005 exerts remarkable efficiency in preclinical studies and was well tolerated in phase I clinical studies in glioblastoma. However, phase II clinical trials utilizing ANG1005 were terminated because of lack of efficacy [179]. Other angiopeptide drug conjugates include ANG1007 (angiopep-2-doxorubicin) [180], ANG1009 (angiopep-2-dimethylglycine etoposide), and ANG4043 (angipep 2-trastuzumab). ANG4043 is a novel brain-penetrating peptide-mAb conjugate that is efficient against HER2-positive intracranial tumors in mice (Table 5). This peptide Ab conjugate retains in vitro binding affinity for the HER2 receptor and antiproliferative potency against HER2-positive BT-474 breast ductal carcinoma cells [181]. Applications of angiopeptides as targeting moieties for other anticancer applications are still under investigation [181-185]. 
Table 1. Luteinizing Hormone-Releasing Hormone (LHRH) cytotoxic analogs.* For additional biological models of these conjugates see [2,154,186].

\begin{tabular}{|c|c|c|c|c|c|c|c|}
\hline $\begin{array}{l}\text { Sequence of the } \\
\text { Targeting Peptide }\end{array}$ & $\begin{array}{l}\text { Name of the } \\
\text { Targeting Peptide }\end{array}$ & Formulation & $\begin{array}{l}\text { Therapeutic } \\
\text { Agent }\end{array}$ & Target & In-Vitro Model & In-Vivo Model & Ref. \\
\hline $\begin{array}{l}\text { GlpHWSYKLRPG-NH2 } \\
\text { (Glp = Pyroglutamic acid) }\end{array}$ & (D-Lys6)LH-RH & PDC & DOX & LHRH & $\begin{array}{l}{ }^{*} \text { Human breast cancer } \\
\text { cells MCF7 }{ }^{\mathrm{a}} \text {, } \\
\text { Mouse mammary } \\
\text { carcinoma cells MXT a, } \\
\text { Human breast cancer } \\
\text { cells MX-1 }{ }^{\mathrm{b}}\end{array}$ & & $\begin{array}{l}\mathrm{a}[126] \\
\mathrm{b}[118]\end{array}$ \\
\hline $\begin{array}{l}\text { GlpHWSYKLRPG-NH2 } \\
\text { (Glp = Pyroglutamic acid) }\end{array}$ & (D-Lys6)LH-RH & PDC & 2-pyrrolino-DOX & LHRH & $\begin{array}{l}{ }^{*} \text { Human breast cancer } \\
\text { cells MX-1 a / } \\
\text { MDA-MB-231 b/ } \\
\text { MDA-MB- } 435^{c}\end{array}$ & $\begin{array}{l}{ }^{*} \mathrm{MX}-1^{\mathrm{a}} / \\
\text { MDA-MB-231 } \mathrm{b} / \\
\text { MDA-MB- } 435^{\mathrm{c}} \text { tumor } \\
\text { in mice }\end{array}$ & $\begin{array}{l}\mathrm{a}[126] \\
\mathrm{b}[127] \\
\mathrm{c}[128]\end{array}$ \\
\hline $\begin{array}{l}\text { Ac-D-Nal(2)-f(4Cl)-D-Pal(3)- } \\
\text { SYkLRPa-NH2 [where Nal(2)= } \\
\text { 3-(2-naphthyl)alanine, Pal(3)= } \\
\text { 3-(3-pyridyl)alanine, and } \mathrm{f}(4 \mathrm{CI})= \\
\text { 4-chloro-D-phenylalanine) }\end{array}$ & $\begin{array}{l}\text { Antagonistic } \\
\text { analog }\end{array}$ & PDC & 2-pyrrolino-DOX & LHRH & $\begin{array}{l}{ }^{*} \text { Human breast cancer } \\
\text { cells MCF7 a, } \\
\text { Mouse mammary } \\
\text { carcinoma cells MXT a }\end{array}$ & & a [126] \\
\hline QHWSYkLRP-NH-Et & $\begin{array}{l}\text { (D-Lys6)LH-RH } \\
\text { Des-Gly10, } \\
\text { Pro-NHEt9 }\end{array}$ & $\begin{array}{l}\text { PEGylated } \\
\text { carrier system }\end{array}$ & CPT & LHRH & $\begin{array}{l}\text { Human ovarian cancer } \\
\text { cells A2780 }\end{array}$ & & [134] \\
\hline $\begin{array}{l}\text { GlpHWSYKLRPG-NH2 } \\
\text { (Glp = Pyroglutamic acid) }\end{array}$ & (D-Lys6)LH-RH & PDC & Curcumin & LHRH & $\begin{array}{l}\text { Human pancreatic } \\
\text { cancer cells MIAPaCa-2, } \\
\text { BxPC-3 and Panc- } 1\end{array}$ & $\begin{array}{l}\text { Pancreas cancer-MIA } \\
\text { PaCa-2-tumor in mice }\end{array}$ & [187] \\
\hline
\end{tabular}


Table 2. Targeted drug delivery (TDD) systems based on Arginine-Glycine-Aspartic acid (RGD) sequence as targeting agent. * For additional examples of RGD-therapeutic proteins conjugates see [188]. ** For additional examples of RGD-nanocarriers targeted therapies see [189].

\begin{tabular}{|c|c|c|c|c|c|c|c|}
\hline $\begin{array}{l}\text { Name of the } \\
\text { Targeting Peptide }\end{array}$ & $\begin{array}{l}\text { Sequence of the } \\
\text { Targeting Peptide }\end{array}$ & Formulation & $\begin{array}{l}\text { Therapeutic } \\
\text { Agent }\end{array}$ & Target & In-Vitro Model & In-Vivo Model & Ref. \\
\hline RGD4C & Cyclic CDCRGDCFC & * Fusion protein & $\mathrm{TNF} \alpha$ & $\alpha_{V} \beta_{3}$ & $\begin{array}{l}\text { Human glioblastoma cells U87MG, } \\
\text { Human breast cancer cells MDA-MB-435, } \\
\text { Rat glioma cells C6, } \\
\text { Mouse fibroblast cells L929 }\end{array}$ & $\begin{array}{l}\text { U87MG tumor } \\
\text { in mice, } \\
\text { MDAMB-435 } \\
\text { tumor in mice }\end{array}$ & [190] \\
\hline RGD4C & Cyclic CDCRGDCFC & PDC & DOX & $\alpha_{V} \beta_{3}$ & & $\begin{array}{l}\text { MDAMB-435 } \\
\text { tumor in mice }\end{array}$ & {$[94]$} \\
\hline RGD4C & Bicyclic CDCRGDCFC & $\begin{array}{l}\text { Drug conjugate with } \\
\text { plasmin self immolative } \\
\text { linker vFK }\end{array}$ & DOX & $\alpha_{V} \beta_{3}$ & $\begin{array}{l}\text { Human fibroblast cells HT1080, } \\
\text { Human endothelial cells HUVEC }\end{array}$ & & [191] \\
\hline Acyclic RGD4C & Acyclic CDCRGDCFC & PDC & Doxsaliform & $\alpha_{V} \beta_{3}$ & Human breast cancer cells MDA-MB- 435 & & [95] \\
\hline$c($ RGDfK) & c(RGDfK) & PDC & CLB, CPT & $\alpha_{V} \beta_{3}$ & $\begin{array}{l}\text { Human non-small lung carcinoma } \\
\text { cells H1299, } \\
\text { Murine melanoma cells B16-F10, } \\
\text { Human embryonic kidney cells HEK-293 }\end{array}$ & & [109] \\
\hline$c($ RGDfK) & c(RGDfK) & $\begin{array}{l}\text { Drug conjugate with } \\
\text { dual drug payload }\end{array}$ & CLB, CPT & $\alpha_{V} \beta_{3}$ & $\begin{array}{l}\text { Human non-small lung carcinoma } \\
\text { cells H1299, } \\
\text { Murine melanoma cells B16-F10, } \\
\text { Human embryonic kidney cells HEK-293 }\end{array}$ & & [112] \\
\hline$c($ RGDfK) & $c($ RGDfK) & $\begin{array}{l}\text { PAMAM Drug loaded } \\
\text { PEGylated dendrimers }\end{array}$ & DOX & $\alpha_{V} \beta_{3}$ & Human glioblastoma cells U87MG & & [192] \\
\hline c(RGDfK) & $\mathrm{c}(\mathrm{RGDfK})$ & PEG polymeric micelles & (DACHPt) & $\alpha_{V} \beta_{3 / 5}$ & Human glioblastoma cells U87MG & $\begin{array}{l}\text { U87MG tumor } \\
\text { in mice }\end{array}$ & [193] \\
\hline c(RGDfK) & $c($ RGDfK $)$ & ** Nanoparticles & DOX & $\alpha_{V} \beta_{3 / 5}$ & Human endothelial cells HUVEC & $\begin{array}{l}\text { Pancreas tumor } \\
\text { in mice-murine } \\
\text { R40P cells }\end{array}$ & [194] \\
\hline$c($ RGDfK) & $c($ RGDfK) & PDC & $\mathrm{CPT}$ & $\alpha_{V} \beta_{3}$ & $\begin{array}{l}\text { Human prostate cancer cells PC3, } \\
\text { Human renal carcinoma cells A498, } \\
\text { Human ovarian cancer cells A2780 }\end{array}$ & $\begin{array}{l}\text { A2780 tumor } \\
\text { in mice }\end{array}$ & [195] \\
\hline
\end{tabular}


Table 2. Cont

\begin{tabular}{|c|c|c|c|c|c|c|c|}
\hline $\begin{array}{l}\text { Name of the } \\
\text { Targeting Peptide }\end{array}$ & $\begin{array}{l}\text { Sequence of the } \\
\text { Targeting Peptide }\end{array}$ & Formulation & $\begin{array}{l}\text { Therapeutic } \\
\text { Agent }\end{array}$ & Target & In-Vitro Model & In-Vivo Model & Ref. \\
\hline Celingitide & $\begin{array}{l}\text { cyclic-(N-Me- } \\
\text { VRGDf-NH) }\end{array}$ & PDC & Doxsaliform & $\alpha_{\mathrm{V}} \beta_{3}$ & Human breast cancer cells MDA-MB-435 & & [95] \\
\hline c(RGDyK) & c(RGDyK) & $\begin{array}{l}\text { Drug loaded } \\
\text { PEG-PLA micelles }\end{array}$ & PTX & $\alpha_{V} \beta_{3}$ & Human glioblastoma cells U87MG & $\begin{array}{l}\text { U87MG tumor } \\
\text { in mice }\end{array}$ & [196] \\
\hline c(RGDfS) & $\mathrm{c}(\mathrm{RGDfS})$ & PDC & CLB & $\alpha_{\mathrm{V}} \beta_{3}$ & $\begin{array}{l}\text { Human non-small lung carcinoma } \\
\text { cells H1299, } \\
\text { Murine melanoma cells B16-F10, } \\
\text { Human embryonic kidney cells HEK-293 }\end{array}$ & & [109] \\
\hline $\mathrm{E}[\mathrm{c}(\mathrm{RGDyK})] 2$ & $\mathrm{E}[\mathrm{c}(\mathrm{RGDyK})] 2$ & PDC & PTX & $\alpha_{V} \beta_{3}$ & Human breast cancer cells MDA-MB-435 & $\begin{array}{l}\text { MDA-MB-435 } \\
\text { tumor in mice }\end{array}$ & [96] \\
\hline E-[c(RGDfK)2] & $\begin{array}{l}\text { divalent cyclic peptide } \\
\text { E-[c(RGDfK)2] }\end{array}$ & $\begin{array}{l}\text { PGA nano-scaled } \\
\text { conjugate }\end{array}$ & PTX & & $\begin{array}{l}\text { Human glioblastoma cells U87MG, } \\
\text { Murine breast cancer cells 4T1, } \\
\text { Human endothelial cells HUVEC }\end{array}$ & & [197] \\
\hline E-[c(RGDfK)2] & $\mathrm{E}-[\mathrm{c}(\mathrm{RGDfK}) 2]$ & $\begin{array}{l}\text { Peptide drug conjugate } \\
\text { with the MMP2/9 } \\
\text { sensitive linker } \\
\text { GPLGILG }\end{array}$ & DOX & $\alpha_{V} \beta_{3}$ & $\begin{array}{l}\text { Human endothelial cells HUVEC, } \\
\text { Human ovarian cancer cells OVCAR-3 }\end{array}$ & $\begin{array}{l}\text { OVCAR-3 tumor } \\
\text { in mice }\end{array}$ & [198] \\
\hline E-[c(RGDfK)2] & $\begin{array}{l}\text { divalent cyclic peptide } \\
\text { E-[c(RGDfK)2] }\end{array}$ & PDC & PTX & $\alpha_{V} \beta_{3}$ & Human endothelial cells HUVEC & $\begin{array}{l}\text { ovarian cancer- } \\
\text { OVCAR-3- } \\
\text { tumor in mice }\end{array}$ & [199] \\
\hline
\end{tabular}


Table 3. Somatostatin cytotoxic analogs. * For additional biological models of these conjugates see $[2,154,186,200]$

\begin{tabular}{|c|c|c|c|c|c|c|c|}
\hline $\begin{array}{l}\text { Name of the } \\
\text { Targeting Peptide }\end{array}$ & $\begin{array}{l}\text { Sequence of the } \\
\text { Targeting Peptide }\end{array}$ & Formulation & $\begin{array}{l}\text { Therapeutic } \\
\text { Agent }\end{array}$ & Target & In-Vitro Model & In-Vivo Model & Ref. \\
\hline RC-160 & Cyclic fCYwKVCW-NH & PDC & $\begin{array}{l}\text { 2-Pyrrolino-DOX, } \\
\text { DOX }\end{array}$ & SSTRs & & $\begin{array}{l}{ }^{*} \text { MDA-MB- } 435 \text { tumor } \\
\text { in mice, mouse } \\
\text { mammary } \\
\text { carcinoma-MXT in } \\
\text { mice, Dunning AT-1 } \\
\text { prostate cancers in rat }\end{array}$ & {$[201]$} \\
\hline RC-121 & Cyclic fCYwKVCT-NH ${ }_{2}$ & PDC & MTX & SSTRs & & $\begin{array}{l}\text { Pancreas cancer-MIA } \\
\text { PaCa-2-tumor in mice }\end{array}$ & [202] \\
\hline RC-121 & Cyclic fCYwKVCT-NH ${ }_{2}$ & PDC & $\begin{array}{l}\text { 2-Pyrrolino-DOX, } \\
\text { DOX }\end{array}$ & SSTRs & $\begin{array}{l}\text { *Human gastric cancer cells MKN-45, } \\
\text { Human breast cancer cells MDA-MB-231, } \\
\text { Human prostate cancer cells-PC-3, } \\
\text { Human pancreatic cancer cells-MIA PaCa2, } \\
\text { Human SCLC cells H-345 }\end{array}$ & $\begin{array}{l}{ }^{*} \text { MDA-MB- } 435 \text { tumor } \\
\text { in mice, mouse } \\
\text { mammary } \\
\text { carcinoma-MXT in } \\
\text { mice, Dunning AT-1 } \\
\text { prostate cancer in rat }\end{array}$ & [201] \\
\hline $3207-86$ & & PDC & $\begin{array}{l}\text { Amonafide, } \\
\text { ABT-751, CPT, } \\
\text { COMB, CLB }\end{array}$ & SSTR2 & $\begin{array}{l}\text { Human non-small lung carcinoma cells H1299, } \\
\text { Human embryonic kidney cells HEK-293, } \\
\text { Human colon cancer cells HTC 116, } \\
\text { Human prostate cancer cells TRAMP C2 }\end{array}$ & & {$[161]$} \\
\hline
\end{tabular}


Table 4. Bombesin (BN) cytotoxic analogs. ${ }^{*}$ For additional biological models of these conjugates see [2,186]. ${ }^{* *}$ For additional BN analogs with 2-pyrrolino-DOX and DOX tested in the same biological models see [170].

\begin{tabular}{|c|c|c|c|c|c|c|c|}
\hline $\begin{array}{l}\text { Name of the } \\
\text { Targeting Peptide }\end{array}$ & $\begin{array}{l}\text { Sequence of the } \\
\text { Targeting Peptide }\end{array}$ & Formulation & Therapeutic Agent & Target & In-Vitro Model & In-Vivo Model & Ref. \\
\hline RC-3094 & $\begin{array}{l}\text { ** QWAVGHL- }(\mathrm{CH} 2- \\
\mathrm{NH})-\mathrm{L}-\mathrm{NH}_{2}\end{array}$ & PDC & $\begin{array}{l}\text { 2-pyrrolino-DOX, } \\
\text { DOX }\end{array}$ & Bombesin & $\begin{array}{l}\text { *Human pancreatic cancer cells CFPAC- } 1 \text {, } \\
\text { Human lung cancer cells DMS-53, } \\
\text { Human prostate cancer cells PC-3, } \\
\text { Human gastric cancer cells MKN-45 }\end{array}$ & & [170] \\
\hline RC-3094 & $\begin{array}{l}\text { QWAVGHL- }(\mathrm{CH} 2- \\
\mathrm{NH})-\mathrm{L}-\mathrm{NH}_{2}\end{array}$ & PDC & $\begin{array}{l}\text { 2-pyrrolino-DOX, } \\
\text { DOX }\end{array}$ & Bombesin & ${ }^{*}$ Human SCLC cells NCI-H-69 & $\begin{array}{l}{ }^{*} \mathrm{NCI}-\mathrm{H}-69 \\
\text { tumor in mice }\end{array}$ & [203] \\
\hline $\mathrm{BBN}(7-13)$ & WAVGHL-NH ${ }_{2}$ & $\begin{array}{l}\text { PDC with } \\
\text { PEGylated linker }\end{array}$ & PTX & Bombesin & Human SCLC cells NCI-H-69 & & [204] \\
\hline
\end{tabular}

Table 5. Angiopep-2 cytotoxic analogs.

\begin{tabular}{|c|c|c|c|c|c|c|c|}
\hline $\begin{array}{l}\text { Name of the } \\
\text { Targeting Peptide }\end{array}$ & $\begin{array}{l}\text { Sequence of the } \\
\text { Targeting Peptide }\end{array}$ & Formulation & $\begin{array}{l}\text { Therapeutic } \\
\text { Agent }\end{array}$ & Target & In-Vitro Model & In-Vivo Model & Ref. \\
\hline Angiopep-2 & TFFYGGSRGKRNNFKTEEY & PDC & $3 \times \mathrm{PXT}$ & $\begin{array}{l}\text { Low-density lipoprotein } \\
\text { receptor (LDLr) }\end{array}$ & & U87 glioma & [180] \\
\hline Angiopep-2 & TFFYGGSRGKRNNFKTEEY & PDC & $3 \times \mathrm{DOX}$ & $\begin{array}{l}\text { Low-density lipoprotein } \\
\text { receptor (LDLr) }\end{array}$ & $\begin{array}{l}\text { Glioblastoma (U87 MG) } \\
\text { Hepatocarcinoma (SK-Hep-1) } \\
\text { Lung carcinoma (NCI-H460) }\end{array}$ & U87 glioma & [180] \\
\hline Angiopep-2 & TFFYGGSRGKRNNFKTEEY & PDC & $\begin{array}{l}\text { dimethylglycine } \\
\text { etoposide (ETO) }\end{array}$ & $\begin{array}{l}\text { Low-density lipoprotein } \\
\text { receptor (LDLr) }\end{array}$ & $\begin{array}{l}\text { Glioblastoma (U87 MG) } \\
\text { Hepatocarcinoma (SK-Hep-1) } \\
\text { Lung carcinoma (NCI-H460) }\end{array}$ & U87 glioma & [180] \\
\hline Angiopep-2 & TFFYGGSRGKRNNFKTEEY & $\begin{array}{l}\text { Peptide-Ab } \\
\text { Conjugate }\end{array}$ & Trastuzumab & $\begin{array}{l}\text { Low-density lipoprotein } \\
\text { receptor (LDLr) }\end{array}$ & $\begin{array}{l}\text { HER2-positive BT- } 474 \text { breast } \\
\text { ductal carcinoma cells }\end{array}$ & $\begin{array}{l}\text { HER2-positive } \\
\text { intracranial } \\
\text { tumors in mice }\end{array}$ & [181] \\
\hline
\end{tabular}




\section{Summary and Conclusions}

This review has focused on and compared vital parameters of several advanced targeted drug delivery systems. We envisage that these technologies will continue to improve and demonstrate their clinical effectiveness. These technologies are developing in parallel to other drug delivery strategies, which also present technical challenges that need to be overcome. For example, Antibody Drug Conjugates (ADCs) are effective drug delivery systems but present limitations such as complexity of preparation and manufacture, irreproducibility and only modest solid tumor penetrability [205]. Despite these drawbacks ADCs are promising therapeutic modalities and have generated intense interest in recent years. Currently, there are 271 ongoing clinical trials involving ADCs (www.clinicaltrials.gov), suggesting that in the coming years at least several more ADCs will receive regulatory approval. Nanoparticle-drug conjugates (NDCs) are another example. These targeted vehicles successfully extend the circulation time and improve the accumulation and uptake of drugs in tumors due to the Enhanced Permeability and Retention (EPR) phenomenon associated with tumor vasculature. In addition, nanoparticles can be utilized as nano-theranostics, by incorporation of therapeutic and diagnostic agents allowing for simultaneous detection and treatment of tumors [206]. However, NDCs are prone to the same challenges as ADCs, including difficulties in achieving reproducible and controlled synthesis. In addition the EPR effect is unpredictable, and there is currently a lack of a universal standard for evaluating the potent cytotoxicity of NDCs.

Fortunately, PDCs combine the advantages of both ADCs and NDCs and obviate many of their disadvantages. The synthetic and structure-activity relationship strategies mentioned above for rational design and manipulation of the peptide carriers overcome perceived shortcomings of using only linear peptides. These techniques significantly reduce their sensitivity to enzymatic degradation, extensive renal filtration and nonspecific uptake into tissues and organs, all of which contribute to favorable bioavailability and increased half-life in the circulation as compared to other carriers. Another merit of PDCs is their fast and completely reproducible synthesis mostly by solid phase chemistry, enabling their utilization in high throughput screening for rapid optimization of structural parameters. Progress in optimization of "smart" linkers with various activation modes (enzymatic and $\mathrm{pH}$ dependent), identification of novel targets and recent discoveries of new peptide carriers for conjugation in TDD [207] will pave the way for greater insight into the contribution of these various characteristics to PDC efficacy, safety and pharmacokinetic properties. Moreover, the development of multi-drug PDCs therapies, namely PDCs that carry cytotoxic "cocktails" instead of single drug, will continue to grow. In conclusion, targeted drug therapies will contribute to major developments in cancer therapy in the near future. ADCs, NDCs and PDCs each have advantages and disadvantages and a better understanding of these will allow a more rational design of combined targeted therapies.

Acknowledgments: The authors thank to Ms. Reut Cohen for the graphical assistance.

Conflicts of Interest: The authors declare no conflict of interest.

\section{References}

1. Marchetti, C.; Palaia, I.; Giorgini, M.; De Medici, C.; Iadarola, R.; Vertechy, L.; Domenici, L.; Di Donato, V.; Tomao, F.; Muzii, L.; et al. Targeted drug delivery via folate receptors in recurrent ovarian cancer: A review. OncoTargets Ther. 2014, 7, 1223-1236. [CrossRef] [PubMed]

2. Schally, A.V.; Nagy, A. Chemotherapy targeted to cancers through tumoral hormone receptors. Trends Endocrinol. Metab. 2004, 15, 300-310. [CrossRef] [PubMed]

3. Firer, M.A.; Gellerman, G. Targeted drug delivery for cancer therapy: The other side of antibodies. J. Hematol. Oncol. 2012, 5, 70. [CrossRef] [PubMed]

4. Smith, G.P. Filamentous fusion phage: Novel expression vectors that display cloned antigens on the virion surface. Science 1985, 228, 1315-1317. [CrossRef] [PubMed] 
5. Kehoe, J.W.; Kay, B.K. Filamentous phage display in the new millennium. Chem. Rev. 2005, 105, 4056-4072. [CrossRef] [PubMed]

6. Pande, J.; Szewczyk, M.M.; Grover, A.K. Phage display: Concept, innovations, applications and future. Biotechnol. Adv. 2010, 28, 849-858. [CrossRef] [PubMed]

7. Babickova, J.; Tothova, L.; Boor, P.; Celec, P. In vivo phage display-A discovery tool in molecular biomedicine. Biotechnol. Adv. 2013, 31, 1247-1259. [CrossRef] [PubMed]

8. Kathlynn, C.B. Peptidic tumor targeting agents: The road from phage display peptide selections to clinical applications. Curr. Pharm. Des. 2010, 16, 1040-1054.

9. Molek, P.; Strukelj, B.; Bratkovic, T. Peptide phage display as a tool for drug discovery: Targeting membrane receptors. Molecules 2011, 16, 857-887. [CrossRef] [PubMed]

10. Matochko, W.L.; Chu, K.; Jin, B.; Lee, S.W.; Whitesides, G.M.; Derda, R. Deep sequencing analysis of phage libraries using illumina platform. Methods 2012, 58, 47-55. [CrossRef] [PubMed]

11. Geysen, H.M.; Meloen, R.H.; Barteling, S.J. Use of peptide synthesis to probe viral antigens for epitopes to a resolution of a single amino acid. Proc. Natl. Acad. Sci. USA 1984, 81, 3998-4002. [CrossRef] [PubMed]

12. Jung, G.; Beck-Sickinger, A.G. Multiple peptide synthesis methods and their applications. New synthetic methods (87). Angew. Chem. Int. Ed. Engl. 1992, 31, 367-383. [CrossRef]

13. Maeji, N.J.; Bray, A.M.; Geysen, H.M. Multi-pin peptide synthesis strategy for T cell determinant analysis. J. Immunol. Methods 1990, 134, 23-33. [CrossRef]

14. Frank, R. The spot-synthesis technique: Synthetic peptide arrays on membrane supports_Principles and applications. J. Immunol. Methods 2002, 267, 13-26. [CrossRef]

15. Lam, K.S.; Lebl, M.; Krchňák, V. The "one-bead-one-compound” combinatorial library method. Chem. Rev. 1997, 97, 411-448. [CrossRef] [PubMed]

16. Tribbick, G. Multipin peptide libraries for antibody and receptor epitope screening and characterization. J. Immunol. Methods 2002, 267, 27-35. [CrossRef]

17. Fleeman, R.; LaVoi, T.M.; Santos, R.G.; Morales, A.; Nefzi, A.; Welmaker, G.S.; Medina-Franco, J.L.; Giulianotti, M.A.; Houghten, R.A.; Shaw, L.N. Combinatorial libraries as a tool for the discovery of novel, broad-spectrum antibacterial agents targeting the eskape pathogens. J. Med. Chem. 2015, 58, 3340-3355. [CrossRef] [PubMed]

18. Mondal, M.; Hirsch, A.K. Dynamic combinatorial chemistry: A tool to facilitate the identification of inhibitors for protein targets. Chem. Soc. Rev. 2015, 44, 2455-2488. [CrossRef] [PubMed]

19. Bhattacharyya, S. Combinatorial approaches in anticancer drug discovery: Recent advances in design and synthesis. Curr. Med. Chem. 2001, 8, 1383-1404. [CrossRef] [PubMed]

20. Eichler, J. Synthetic peptide arrays and peptide combinatorial libraries for the exploration of protein-ligand interactions and the design of protein inhibitors. Comb. Chem. High Throughput Screen. 2005, 8, 135-143. [CrossRef] [PubMed]

21. Liu, R.; Enstrom, A.M.; Lam, K.S. Combinatorial peptide library methods for immunobiology research. Exp. Hematol. 2003, 31, 11-30. [CrossRef]

22. Gray, B.P.; Brown, K.C. Combinatorial peptide libraries: Mining for cell-binding peptides. Chem. Rev. 2014, 114, 1020-1081. [CrossRef] [PubMed]

23. Aina, O.H.; Liu, R.; Sutcliffe, J.L.; Marik, J.; Pan, C.-X.; Lam, K.S. From combinatorial chemistry to cancer-targeting peptides. Mol. Pharm. 2007, 4, 631-651. [CrossRef] [PubMed]

24. Marani, M.M.; Martínez Ceron, M.C.; Giudicessi, S.L.; de Oliveira, E.; Côté, S.; Erra-Balsells, R.; Albericio, F.; Cascone, O.; Camperi, S.A. Screening of one-bead-one-peptide combinatorial library using red fluorescent dyes. Presence of positive and false positive beads. J. Comb. Chem. 2009, 11, 146-150. [CrossRef] [PubMed]

25. Svensen, N.; Diaz-Mochon, J.J.; Dhaliwal, K.; Planonth, S.; Dewar, M.; Armstrong, J.D.; Bradley, M. Screening of a combinatorial homing peptide library for selective cellular delivery. Angew. Chem. Int. Ed. 2011, 50, 6133-6136. [CrossRef] [PubMed]

26. Nielsen, P.E.; Egholm, M.; Berg, R.H.; Buchardt, O. Sequence-selective recognition of DNA by strand displacement with a thymine-substituted polyamide. Science 1991, 254, 1497-1500. [CrossRef] [PubMed]

27. Egholm, M.; Buchardt, O.; Nielsen, P.E.; Berg, R.H. Peptide nucleic acids (PNA). Oligonucleotide analogs with an achiral peptide backbone. J. Am. Chem. Soc. 1992, 114, 1895-1897. [CrossRef] 
28. Demidov, V.V.; Potaman, V.N.; Frank-Kamenetskil, M.D.; Egholm, M.; Buchard, O.; Sönnichsen, S.H.; Nlelsen, P.E. Stability of peptide nucleic acids in human serum and cellular extracts. Biochem. Pharmacol. 1994, 48, 1310-1313. [CrossRef]

29. Egholm, M.; Behrens, C.; Christensen, L.; Berg, R.H.; Nielsen, P.E.; Buchardt, O. Peptide nucleic acids containing adenine or guanine recognize thymine and cytosine in complementary DNA sequences. J. Chem. Soc. Chem. Commun. 1993, 800-801. [CrossRef]

30. Egholm, M.; Nielsen, P.E.; Buchardt, O.; Berg, R.H. Recognition of guanine and adenine in DNA by cytosine and thymine containing peptide nucleic acids (PNA). J. Am. Chem. Soc. 1992, 114, 9677-9678. [CrossRef]

31. Frank, R. Spot-synthesis: An easy technique for the positionally addressable, parallel chemical synthesis on a membrane support. Tetrahedron 1992, 48, 9217-9232. [CrossRef]

32. Hilpert, K.; Winkler, D.F.H.; Hancock, R.E.W. Peptide arrays on cellulose support: Spot synthesis, a time and cost efficient method for synthesis of large numbers of peptides in a parallel and addressable fashion. Nat. Protoc. 2007, 2, 1333-1349. [CrossRef] [PubMed]

33. Reineke, U.; Volkmer-Engert, R.; Schneider-Mergener, J. Applications of peptide arrays prepared by the spot-technology. Curr. Opin. Biotechnol. 2001, 12, 59-64. [CrossRef]

34. Frank, R.; Overwin, H. Spot Synthesis. In Epitope Mapping Protocols; Morris, G.E., Ed.; Humana Press: Totowa, NJ, USA, 1996; pp. 149-169.

35. Ast, T.; Heine, N.; Germeroth, L.; Schneider-Mergener, J.; Wenschuh, H. Efficient assembly of peptomers on continuous surfaces. Tetrahedron Lett. 1999, 40, 4317-4318. [CrossRef]

36. Weiler, J.; Gausepohl, H.; Hauser, N.; Jensen, O.N.; Hoheisel, J.D. Hybridisation based DNA screening on peptide nucleic acid (PNA) oligomer arrays. Nucleic Acids Res. 1997, 25, 2792-2799. [CrossRef] [PubMed]

37. Scharn, D.; Wenschuh, H.; Reineke, U.; Schneider-Mergener, J.; Germeroth, L. Spatially addressed synthesis of amino- and amino-oxy-substituted 1,3,5-triazine arrays on polymeric membranes. J. Comb. Chem. 2000, 2, 361-369. [CrossRef] [PubMed]

38. Zander, N. New planar substrates for the in situ synthesis of peptide arrays. Mol. Divers. 2004, 8, 189-195. [CrossRef] [PubMed]

39. Eichler, J.; Bienert, M.; Stierandova, A.; Lebl, M. Evaluation of cotton as a carrier for solid-phase peptide synthesis. Pept. Res. 1991, 4, 296-307. [PubMed]

40. Wang, Z.; Laursen, R.A. Multiple peptide synthesis on polypropylene membranes for rapid screening of bioactive peptides. Pept. Res. 1992, 5, 275-280. [PubMed]

41. Volkmer-Engert, R.; Hoffmann, B.; Schneider-Mergener, J. Stable attachment of the hmb-linker to continuous cellulose membranes for parallel solid phase spot synthesis. Tetrahedron Lett. 1997, 38, 1029-1032. [CrossRef]

42. Licha, K.; Bhargava, S.; Rheinländer, C.; Becker, A.; Schneider-Mergener, J.; Volkmer-Engert, R. Highly parallel nano-synthesis of cleavable peptide-dye conjugates on cellulose membranes. Tetrahedron Lett. 2000, 41, 1711-1715. [CrossRef]

43. Frank, R. Simultaneous and combinatorial chemical synthesis techniques for the generation and screening of molecular diversity. J. Biotechnol. 1995, 41, 259-272. [CrossRef]

44. Werle, M.; Bernkop-Schnürch, A. Strategies to improve plasma half life time of peptide and protein drugs. Amino Acids 2006, 30, 351-367. [CrossRef] [PubMed]

45. Powell, M.F.; Stewart, T.; Otvos, L., Jr.; Urge, L.; Gaeta, F.C.A.; Sette, A.; Arrhenius, T.; Thomson, D.; Soda, K.; Colon, S.M. Peptide stability in drug development. II. Effect of single amino acid substitution and glycosylation on peptide reactivity in human serum. Pharm. Res. 1993, 10, 1268-1273. [CrossRef] [PubMed]

46. Harris, A.G. Somatostatin and somatostatin analogs: Pharmacokinetics and pharmacodynamic effects. Gut 1994, 35, S1-S4. [CrossRef] [PubMed]

47. Vanhee, P.; van der Sloot, A.M.; Verschueren, E.; Serrano, L.; Rousseau, F.; Schymkowitz, J. Computational design of peptide ligands. Trends Biotechnol. 2011, 29, 231-239. [CrossRef] [PubMed]

48. Fernandez-Ballester, G.; Beltrao, P.; Gonzalez, J.M.; Song, Y.-H.; Wilmanns, M.; Valencia, A.; Serrano, L. Structure-based prediction of the saccharomyces cerevisiae SH3-ligand interactions. J. Mol. Biol. 2009, 388, 902-916. [CrossRef] [PubMed]

49. Kiel, C.; Wohlgemuth, S.; Rousseau, F.; Schymkowitz, J.; Ferkinghoff-Borg, J.; Wittinghofer, F.; Serrano, L. Recognizing and defining true ras binding domains II: In silico prediction based on homology modelling and energy calculations. J. Mol. Biol. 2005, 348, 759-775. [CrossRef] [PubMed] 
50. Theodoropoulos, D.; Poulos, C.; Gatos, D.; Cordopatis, P.; Escher, E.; Mizrahi, J.; Regoli, D.; Dalietos, D.; Furst, A.; Lee, T.D. Conformationally restricted C-terminal peptides of substance P. Synthesis, mass spectral analysis and pharmacological properties. J. Med. Chem. 1985, 28, 1536-1539. [CrossRef] [PubMed]

51. Darman, P.S.; Landis, G.C.; Smits, J.R.; Hirning, L.D.; Gulya, K.; Yamamura, H.I.; Burks, T.F.; Hruby, V.J. Conformationally restricted cyclic analogues of substance P: Insight into the receptor binding process. Biochem. Biophys. Res. Commun. 1985, 127, 656-662. [CrossRef]

52. Gazal, S.; Gelerman, G.; Ziv, O.; Karpov, O.; Litman, P.; Bracha, M.; Afargan, M.; Gilon, C. Human somatostatin receptor specificity of backbone-cyclic analogues containing novel sulfur building units. J. Med. Chem. 2002, 45, 1665-1671. [CrossRef] [PubMed]

53. Gazal, S.; Gellerman, G.; Glukhov, E.; Gilon, C. Synthesis of novel protected $N^{\alpha}$ ( $\omega$-thioalkyl) amino acid building units and their incorporation in backbone cyclic disulfide and thioetheric bridged peptides. J. Pept. Res. Off. J. Am. Pept. Soc. 2001, 58, 527-539. [CrossRef]

54. Jiang, S.; Gazal, S.; Gelerman, G.; Ziv, O.; Karpov, O.; Litman, P.; Bracha, M.; Afargan, M.; Gilon, C.; Goodman, M. A bioactive somatostatin analog without a type ii' beta-turn: Synthesis and conformational analysis in solution. J. Pept. Sci. 2001, 7, 521-528. [CrossRef] [PubMed]

55. Gazal, S.; Gellerman, G.; Gilon, C. Novel gly building units for backbone cyclization: Synthesis and incorporation into model peptides. Peptides 2003, 24, 1847-1852. [CrossRef] [PubMed]

56. Gellerman, G.; Elgavi, A.; Salitra, Y.; Kramer, M. Facile synthesis of orthogonally protected amino acid building blocks for combinatorial n-backbone cyclic peptide chemistry. J. Pept. Res. 2001, 57, 277-291. [CrossRef] [PubMed]

57. Dooley, C.T.; Houghten, R.A. The use of positional scanning synthetic peptide combinatorial libraries for the rapid determination of opioid receptor ligands. Life Sci. 1993, 52, 1509-1517. [CrossRef]

58. Bionda, N.; Fleeman, R.M.; de la Fuente-Núñez, C.; Rodriguez, M.C.; Reffuveille, F.; Shaw, L.N.; Pastar, I.; Davis, S.C.; Hancock, R.E.W.; Cudic, P. Identification of novel cyclic lipopeptides from a positional scanning combinatorial library with enhanced antibacterial and antibiofilm activities. Eur. J. Med. Chem. 2016, 108, 354-363. [CrossRef] [PubMed]

59. Pierschbacher, M.D.; Ruoslahti, E. Cell attachment activity of fibronectin can be duplicated by small synthetic fragments of the molecule. Nature 1984, 309, 30-33. [CrossRef] [PubMed]

60. Pierschbacher, M.D.; Ruoslahti, E. Variants of the cell recognition site of fibronectin that retain attachment-promoting activity. Proc. Natl. Acad. Sci. USA 1984, 81, 5985-5988. [CrossRef] [PubMed]

61. Yamada, K.M.; Kennedy, D.W. Dualistic nature of adhesive protein function: Fibronectin and its biologically active peptide fragments can autoinhibit fibronectin function. J. Cell Biol. 1984, 99, 29-36. [CrossRef] [PubMed]

62. Gartner, T.K.; Bennett, J.S. The tetrapeptide analogue of the cell attachment site of fibronectin inhibits platelet aggregation and fibrinogen binding to activated platelets. J. Biol. Chem. 1985, 260, 11891-11894. [PubMed]

63. Plow, E.F.; Pierschbacher, M.D.; Ruoslahti, E.; Marguerie, G.A.; Ginsberg, M.H. The effect of arg-gly-asp-containing peptides on fibrinogen and von willebrand factor binding to platelets. Proc. Natl. Acad. Sci. USA 1985, 82, 8057-8061. [CrossRef] [PubMed]

64. Suzuki, S.; Oldberg, A.; Hayman, E.G.; Pierschbacher, M.D.; Ruoslahti, E. Complete amino acid sequence of human vitronectin deduced from cdna. Similarity of cell attachment sites in vitronectin and fibronectin. EMBO J. 1985, 4, 2519-2524. [PubMed]

65. Gardner, J.M.; Hynes, R.O. Interaction of fibronectin with its receptor on platelets. Cell 1985, 42, 439-448. [CrossRef]

66. Damsky, C.H.; Wylie, D.E.; Buck, C.A. Studies on the function of cell surface glycoproteins. II. Possible role of surface glycoproteins in the control of cytoskeletal organization and surface morphology. J. Cell Biol. 1979, 80, 403-415. [CrossRef] [PubMed]

67. Knudsen, K.A.; Horwitz, A.F.; Buck, C.A. A monoclonal antibody identifies a glycoprotein complex involved in cell-substratum adhesion. Exp. Cell Res. 1985, 157, 218-226. [CrossRef]

68. Neff, N.T.; Lowrey, C.; Decker, C.; Tovar, A.; Damsky, C.; Buck, C.; Horwitz, A.F. A monoclonal antibody detaches embryonic skeletal muscle from extracellular matrices. J. Cell Biol. 1982, 95, 654-666. [CrossRef] [PubMed]

69. Greve, J.M.; Gottlieb, D.I. Monoclonal antibodies which alter the morphology of cultured chick myogenic cells. J. Cell. Biochem. 1982, 18, 221-229. [CrossRef] [PubMed] 
70. Tarone, G.; Galetto, G.; Prat, M.; Comoglio, P.M. Cell surface molecules and fibronectin-mediated cell adhesion: Effect of proteolytic digestion of membrane proteins. J. Cell Biol. 1982, 94, 179-186. [CrossRef] [PubMed]

71. Brown, P.J.; Juliano, R.L. Selective inhibition of fibronectin-mediated cell adhesion by monoclonal antibodies to a cell-surface glycoprotein. Science 1985, 228, 1448-1451. [CrossRef] [PubMed]

72. Chapman, A.E. Characterization of a $140 \mathrm{Kd}$ cell surface glycoprotein involved in myoblast adhesion. J. Cell. Biochem. 1984, 25, 109-121. [CrossRef] [PubMed]

73. Giancotti, F.G.; Comoglio, P.M.; Tarone, G. Fibronectin-plasma membrane interaction in the adhesion of hemopoietic cells. J. Cell Biol. 1986, 103, 429-437. [CrossRef] [PubMed]

74. Pytela, R.; Pierschbacher, M.D.; Ruoslahti, E. Identification and isolation of a $140 \mathrm{kd}$ cell surface glycoprotein with properties expected of a fibronectin receptor. Cell 1985, 40, 191-198. [CrossRef]

75. Tamkun, J.W.; DeSimone, D.W.; Fonda, D.; Patel, R.S.; Buck, C.; Horwitz, A.F.; Hynes, R.O. Structure of integrin, a glycoprotein involved in the transmembrane linkage between fibronectin and actin. Cell 1986, 46, 271-282. [CrossRef]

76. Hynes, R.O. Integrins: Bidirectional, allosteric signaling machines. Cell 2002, 110, 673-687. [CrossRef]

77. Schwartz, M.A.; Schaller, M.D.; Ginsberg, M.H. Integrins: Emerging paradigms of signal transduction. Annu. Rev. Cell Dev. Biol. 1995, 11, 549-599. [CrossRef] [PubMed]

78. Taverna, D.; Crowley, D.; Connolly, M.; Bronson, R.T.; Hynes, R.O. A direct test of potential roles for $\beta 3$ and $\beta 5$ integrins in growth and metastasis of murine mammary carcinomas. Cancer Res. 2005, 65, 10324-10329. [CrossRef] [PubMed]

79. Danen, E.H.J.; van Kraats, A.A.; Cornelissen, I.M.H.A.; Ruiter, D.J.; van Muijen, G.N.P. Integrin $\beta 3$ cDNA transfection into a highly metastatic $\alpha \mathrm{v} \beta 3$-negative human melanoma cell line inhibits invasion and experimental metastasis. Biochem. Biophys. Res. Commun. 1996, 226, 75-81. [CrossRef] [PubMed]

80. Takayama, S.; Ishii, S.; Ikeda, T.; Masamura, S.; Doi, M.; Kitajima, M. The relationship between bone metastasis from human breast cancer and integrin $\alpha \mathrm{v} \beta 3$ expression. Anticancer Res. 2005, 25, 79-83. [PubMed]

81. Avraamides, C.J.; Garmy-Susini, B.; Varner, J.A. Integrins in angiogenesis and lymphangiogenesis. Nat. Rev. Cancer 2008, 8, 604-617. [CrossRef] [PubMed]

82. Vellon, L.; Menendez, J.A.; Lupu, R. $\alpha \mathrm{v} \beta 3$ integrin regulates heregulin (HRG)-induced cell proliferation and survival in breast cancer. Oncogene 2005, 24, 3759-3773. [CrossRef] [PubMed]

83. Galliher, A.J.; Schiemann, W.P. Src Phosphorylates Tyr ${ }^{284}$ in TGF- $\beta$ Type II Receptor and Regulates TGF- $\beta$ Stimulation of p38 MAPK during Breast Cancer Cell Proliferation and Invasion. Canser Res. 2007, 67, 3752-3758. [CrossRef] [PubMed]

84. Chen, Q.; Manning, C.; Millar, H.; McCabe, F.; Ferrante, C.; Sharp, C.; Shahied-Arruda, L.; Doshi, P.; Nakada, M.; Anderson, G.M. Cnto 95, a fully human anti $\alpha \mathrm{v}$ integrin antibody, inhibits cell signaling, migration, invasion, and spontaneous metastasis of human breast cancer cells. Clin. Exp. Metastasis 2008, 25, 139-148. [CrossRef] [PubMed]

85. Felding-Habermann, B.; Habermann, R.; Saldívar, E.; Ruggeri, Z.M. Role of 3 integrins in melanoma cell adhesion to activated platelets under flow. J. Biol. Chem. 1996, 271, 5892-5900. [CrossRef] [PubMed]

86. White, D.P.; Caswell, P.T.; Norman, J.C. Av $\beta 3$ and $\alpha 5 \beta 1$ integrin recycling pathways dictate downstream rho kinase signaling to regulate persistent cell migration. J. Cell Biol. 2007, 177, 515-525. [CrossRef] [PubMed]

87. Albelda, S.M.; Mette, S.A.; Elder, D.E.; Stewart, R.; Damjanovich, L.; Herlyn, M.; Buck, C.A. Integrin distribution in malignant melanoma: Association of the $\beta 3$ subunit with tumor progression. Cancer Res. 1990, 50, 6757-6764. [PubMed]

88. Seftor, R.E.; Seftor, E.A.; Gehlsen, K.R.; Stetler-Stevenson, W.G.; Brown, P.D.; Ruoslahti, E.; Hendrix, M.J. Role of the alpha v beta 3 integrin in human melanoma cell invasion. Proc. Natl. Acad. Sci. USA 1992, 89, 1557-1561. [CrossRef] [PubMed]

89. Guo, W.; Giancotti, F.G. Integrin signalling during tumour progression. Nat. Rev. Mol. Cell Biol. 2004, 5, 816-826. [CrossRef] [PubMed]

90. Desgrosellier, J.S.; Cheresh, D.A. Integrins in cancer: Biological implications and therapeutic opportunities. Nat. Rev. Cancer 2010, 10, 9-22. [CrossRef] [PubMed]

91. Cox, D.; Brennan, M.; Moran, N. Integrins as therapeutic targets: Lessons and opportunities. Nat. Rev. Drug Discov. 2010, 9, 804-820. [CrossRef] [PubMed] 
92. Mas-Moruno, C.; Rechenmacher, F.; Kessler, H. Cilengitide: The first anti-angiogenic small molecule drug candidate. Design, synthesis and clinical evaluation. Anticancer Agents Med. Chem. 2010, 10, 753-768. [CrossRef] [PubMed]

93. Chen, K.; Chen, X. Integrin targeted delivery of chemotherapeutics. Theranostics 2011, 1, 189-200. [CrossRef] [PubMed]

94. Arap, W.; Pasqualini, R.; Ruoslahti, E. Cancer treatment by targeted drug delivery to tumor vasculature in a mouse model. Science 1998, 279, 377-380. [CrossRef] [PubMed]

95. Burkhart, D.J.; Kalet, B.T.; Coleman, M.P.; Post, G.C.; Koch, T.H. Doxorubicin-formaldehyde conjugates targeting $\alpha \mathrm{v} \beta 3$ integrin. Mol. Cancer Ther. 2004, 3, 1593-1604. [PubMed]

96. Chen, X.; Plasencia, C.; Hou, Y.; Neamati, N. Synthesis and biological evaluation of dimeric RGD peptide-paclitaxel conjugate as a model for integrin-targeted drug delivery. J. Med. Chem. 2005, 48, 1098-1106. [CrossRef] [PubMed]

97. Danhier, F.; Vroman, B.; Lecouturier, N.; Crokart, N.; Pourcelle, V.; Freichels, H.; Jérôme, C.; Marchand-Brynaert, J.; Feron, O.; Préat, V. Targeting of tumor endothelium by RGD-grafted PLGA-nanoparticles loaded with paclitaxel. J. Control. Release 2009, 140, 166-173. [CrossRef] [PubMed]

98. Chen, X.; Hou, Y.; Tohme, M.; Park, R.; Khankaldyyan, V.; Gonzales-Gomez, I.; Bading, J.R.; Laug, W.E.; Conti, P.S. Pegylated Arg-Gly-Asp peptide: ${ }^{64} \mathrm{Cu}$ labeling and pet imaging of brain tumor $\alpha \mathrm{v} \beta 3$-integrin expression. J. Nucl. Med. 2004, 45, 1776-1783. [PubMed]

99. Wu, Y.; Zhang, X.; Xiong, Z.; Cheng, Z.; Fisher, D.R.; Liu, S.; Gambhir, S.S.; Chen, X. Micropet imaging of glioma integrin $\alpha \mathrm{v} \beta 3$ expression using 64cu-labeled tetrameric rgd peptide. J. Nucl. Med. 2005, 46, 1707-1718. [PubMed]

100. Marinelli, L.; Lavecchia, A.; Gottschalk, K.-E.; Novellino, E.; Kessler, H. Docking studies on $\alpha \mathrm{v} \beta 3$ integrin ligands: Pharmacophore refinement and implications for drug design. J. Med. Chem. 2003, 46, 4393-4404. [CrossRef] [PubMed]

101. Xiong, J.-P.; Stehle, T.; Zhang, R.; Joachimiak, A.; Frech, M.; Goodman, S.L.; Arnaout, M.A. Crystal structure of the extracellular segment of integrin $\alpha \mathrm{v} \beta 3$ in complex with an Arg-Gly-Asp ligand. Science 2002, 296, 151-155. [CrossRef] [PubMed]

102. Goldshaid, L.; Rubinstein, E.; Brandis, A.; Segal, D.; Leshem, N.; Brenner, O.; Kalchenko, V.; Eren, D.; Yecheskel, T.; Salitra, Y.; et al. Novel design principles enable specific targeting of imaging and therapeutic agents to necrotic domains in breast tumors. Breast Cancer Res. 2010, 12, R29. [CrossRef] [PubMed]

103. Hölig, P.; Bach, M.; Völkel, T.; Nahde, T.; Hoffmann, S.; Müller, R.; Kontermann, R.E. Novel RGD lipopeptides for the targeting of liposomes to integrin-expressing endothelial and melanoma cells. Protein Eng. Des. Sel. 2004, 17, 433-441. [CrossRef] [PubMed]

104. Sugahara, K.N.; Teesalu, T.; Karmali, P.P.; Kotamraju, V.R.; Agemy, L.; Greenwald, D.R.; Ruoslahti, E. Coadministration of a tumor-penetrating peptide enhances the efficacy of cancer drugs. Science 2010, 328, 1031-1035. [CrossRef] [PubMed]

105. Jonczyk, A.; Goodman, S.; Diefenbach, B.; Sutter, A.; Holzemann, G.; Kessler, H.; Dechantsreiter, M. Cyclic Adhesion Inhibitors. U.S. Patent US5866540 A, 2 February 1999.

106. Dechantsreiter, M.A.; Planker, E.; Mathä, B.; Lohof, E.; Hölzemann, G.; Jonczyk, A.; Goodman, S.L.; Kessler, H. n-methylated cyclic RGD peptides as highly active and selective $\alpha v \beta 3$ integrin antagonists. J. Med. Chem. 1999, 42, 3033-3040. [CrossRef] [PubMed]

107. Tabatabai, G.; Weller, M.; Nabors, B.; Picard, M.; Reardon, D.; Mikkelsen, T.; Ruegg, C.; Stupp, R. Targeting integrins in malignant glioma. Target. Oncol. 2010, 5, 175-181. [CrossRef] [PubMed]

108. Haubner, R.; Gratias, R.; Diefenbach, B.; Goodman, S.L.; Jonczyk, A.; Kessler, H. Structural and functional aspects of RGD-containing cyclic pentapeptides as highly potent and selective integrin $\alpha \mathrm{v} \beta 3$ antagonists. J. Am. Chem. Soc. 1996, 118, 7461-7472. [CrossRef]

109. Gilad, Y.; Noy, E.; Senderowitz, H.; Albeck, A.; Firer, M.A.; Gellerman, G. Synthesis, biological studies and molecular dynamics of new anticancer rgd-based peptide conjugates for targeted drug delivery. Bioorg. Med. Chem. 2016, 24, 294-303. [CrossRef] [PubMed]

110. Wilson, I.A.; Haft, D.H.; Getzoff, E.D.; Tainer, J.A.; Lerner, R.A.; Brenner, S. Identical short peptide sequences in unrelated proteins can have different conformations: A testing ground for theories of immune recognition. Proc. Natl. Acad. Sci. USA 1985, 82, 5255-5259. [CrossRef] [PubMed] 
111. Kessler, H. Conformation and biological activity of cyclic peptides. Angew. Chem. Int. Ed. 1982, 21, 512-523. [CrossRef]

112. Gilad, Y.; Noy, E.; Senderowitz, H.; Albeck, A.; Firer, M.A.; Gellerman, G. Dual-drug rgd conjugates provide enhanced cytotoxicity to melanoma and non-small lung cancer cells. Biopolymers 2015. [CrossRef] [PubMed]

113. Gellerman, G.; Baskin, S.; Galia, L.; Gilad, Y.; Firer, M.A. Drug resistance to chlorambucil in murine B-cell leukemic cells is overcome by its conjugation to a targeting peptide. Anti-Cancer Drugs 2013, 24, 112-119. [CrossRef] [PubMed]

114. Schally, A.V.; Comaru-Schally, A.M.; Plonowski, A.; Nagy, A.; Halmos, G.; Rekasi, Z. Peptide analogs in the therapy of prostate cancer. Prostate 2000, 45, 158-166. [CrossRef]

115. Miller, W.R.; Scott, W.N.; Morris, R.; Fraser, H.M.; Sharpe, R.M. Growth of human breast cancer cells inhibited by a luteinizing hormone-releasing hormone agonist. Nature 1985, 313, 231-233. [CrossRef] [PubMed]

116. Szepeshazi, K.; Schally, A.V.; Nagy, A. Effective treatment of advanced estrogen-independent MXT mouse mammary cancers with targeted cytotoxic LH-RH analogs. Breast Cancer Res. Treat. 1999, 56, 267-276. [CrossRef] [PubMed]

117. Bajo, A.M.; Schally, A.V.; Halmos, G.; Nagy, A. Targeted doxorubicin-containing luteinizing hormone-releasing hormone analogue AN-152 inhibits the growth of doxorubicin-resistant MX-1 human breast cancers. Clin. Cancer Res. 2003, 9, 3742-3748. [PubMed]

118. Kahan, Z.; Nagy, A.; Schally, A.V.; Halmos, G.; Arencibia, J.M.; Groot, K. Complete regression of MX-1 human breast carcinoma xenografts after targeted chemotherapy with a cytotoxic analog of luteinizing hormone-releasing hormone, AN-207. Cancer 1999, 85, 2608-2615. [CrossRef]

119. Letsch, M.; Schally, A.V.; Szepeshazi, K.; Halmos, G.; Nagy, A. Preclinical evaluation of targeted cytotoxic luteinizing hormone-releasing hormone analogue AN-152 in androgen-sensitive and insensitive prostate cancers. Clin. Cancer Res. 2003, 9, 4505-4513. [PubMed]

120. Plonowski, A.; Schally, A.V.; Nagy, A.; Groot, K.; Krupa, M.; Navone, N.M.; Logothetis, C. Inhibition of in vivo proliferation of MDA-PCa-2b human prostate cancer by a targeted cytotoxic analog of luteinizing hormone-releasing hormone AN-207. Cancer Lett. 2002, 176, 57-63. [CrossRef]

121. Grundker, C.; Volker, P.; Griesinger, F.; Ramaswamy, A.; Nagy, A.; Schally, A.V.; Emons, G. Antitumor effects of the cytotoxic luteinizing hormone-releasing hormone analog AN-152 on human endometrial and ovarian cancers xenografted into nude mice. Am. J. Obstet. Gynecol. 2002, 187, 528-537. [CrossRef] [PubMed]

122. Miyazaki, M.; Nagy, A.; Schally, A.V.; Lamharzi, N.; Halmos, G.; Szepeshazi, K.; Groot, K.; Armatis, P. Growth inhibition of human ovarian cancers by cytotoxic analogues of luteinizing hormone-releasing hormone. J. Natl. Cancer Inst. 1997, 89, 1803-1809. [CrossRef] [PubMed]

123. Miyazaki, M.; Schally, A.V.; Nagy, A.; Lamharzi, N.; Halmos, G.; Szepeshazi, K.; Armatis, P. Targeted cytotoxic analog of luteinizing hormone-releasing hormone AN-207 inhibits growth of OV-1063 human epithelial ovarian cancers in nude mice. Am. J. Obstet. Gynecol. 1999, 180, 1095-1103. [CrossRef]

124. Arencibia, J.M.; Bajo, A.M.; Schally, A.V.; Krupa, M.; Chatzistamou, I.; Nagy, A. Effective treatment of experimental ES-2 human ovarian cancers with a cytotoxic analog of luteinizing hormone-releasing hormone AN-207. Anticancer Drugs 2002, 13, 949-956. [CrossRef] [PubMed]

125. Koppan, M.; Nagy, A.; Schally, A.V.; Plonowski, A.; Halmos, G.; Arencibia, J.M.; Groot, K. Targeted cytotoxic analog of luteinizing hormone-releasing hormone AN-207 inhibits the growth of PC-82 human prostate cancer in nude mice. Prostate 1999, 38, 151-158. [CrossRef]

126. Nagy, A.; Schally, A.V.; Armatis, P.; Szepeshazi, K.; Halmos, G.; Kovacs, M.; Zarandi, M.; Groot, K.; Miyazaki, M.; Jungwirth, A.; et al. Cytotoxic analogs of luteinizing hormone-releasing hormone containing doxorubicin or 2-pyrrolinodoxorubicin, a derivative 500-1000 times more potent. Proc. Natl. Acad. Sci. USA 1996, 93, 7269-7273. [CrossRef] [PubMed]

127. Chatzistamou, L.; Schally, A.V.; Nagy, A.; Armatis, P.; Szepeshazi, K.; Halmos, G. Effective treatment of metastatic MDA-MB-435 human estrogen-independent breast carcinomas with a targeted cytotoxic analogue of luteinizing hormone-releasing hormone AN-207. Clin. Cancer Res. 2000, 6, 4158-4165. [PubMed]

128. Kahan, Z.; Nagy, A.; Schally, A.V.; Halmos, G.; Arencibia, J.M.; Groot, K. Administration of a targeted cytotoxic analog of luteinizing hormone-releasing hormone inhibits growth of estrogen-independent MDA-MB-231 human breast cancers in nude mice. Breast Cancer Res. Treat. 2000, 59, 255-262. [CrossRef] [PubMed] 
129. Engel, J.; Emons, G.; Pinski, J.; Schally, A.V. AEZS-108: A targeted cytotoxic analog of LHRH for the treatment of cancers positive for LHRH receptors. Expert Opin. Investig. Drugs 2012, 21, 891-899. [CrossRef] [PubMed]

130. Hohla, F.; Winder, T.; Greil, R.; Rick, F.G.; Block, N.L.; Schally, A.V. Targeted therapy in advanced metastatic colorectal cancer: Current concepts and perspectives. World J. Gastroenterol. 2014, 20, 6102-6112. [CrossRef] [PubMed]

131. Liu, S.V.; Tsao-Wei, D.D.; Xiong, S.; Groshen, S.; Dorff, T.B.; Quinn, D.I.; Tai, Y.-C.; Engel, J.; Hawes, D.; Schally, A.V.; et al. Phase I, dose-escalation study of the targeted cytotoxic LHRH analog AEZS-108 in patients with castration- and taxane-resistant prostate cancer. Clin. Cancer Res. 2014, 20, 6277-6283. [CrossRef] [PubMed]

132. Leuschner, C.; Enright, F.M.; Gawronska-Kozak, B.; Hansel, W. Human prostate cancer cells and xenografts are targeted and destroyed through luteinizing hormone releasing hormone receptors. Prostate 2003, 56, 239-249. [CrossRef] [PubMed]

133. Schlick, J.-L.; Dulieu, P.; Desvoyes, B.; Adami, P.; Radom, J.; Jouvenot, M. Cytotoxic activity of a recombinant GnRH-PAP fusion toxin on human tumor cell lines. FEBS Lett. 2000, 472, 241-246. [CrossRef]

134. Dharap, S.S.; Qiu, B.; Williams, G.C.; Sinko, P.; Stein, S.; Minko, T. Molecular targeting of drug delivery systems to ovarian cancer by BH3 and LHRH peptides. J. Control. Release 2003, 91, 61-73. [CrossRef]

135. Dharap, S.S.; Wang, Y.; Chandna, P.; Khandare, J.J.; Qiu, B.; Gunaseelan, S.; Sinko, P.J.; Stein, S.; Farmanfarmaian, A.; Minko, T. Tumor-specific targeting of an anticancer drug delivery system by LHRH peptide. Proc Natl Acad Sci USA 2005, 102, 12962-12967. [CrossRef] [PubMed]

136. Patel, Y.C. Somatostatin and its receptor family. Front. Neuroendocrinol. 1999, 20, 157-198. [CrossRef] [PubMed]

137. He, Y.; Yuan, X.M.; Lei, P.; Wu, S.; Xing, W.; Lan, X.L.; Zhu, H.F.; Huang, T.; Wang, G.B.; An, R.; et al. The antiproliferative effects of somatostatin receptor subtype 2 in breast cancer cells. Acta Pharmacol. Sin. 2009, 30, 1053-1059. [CrossRef] [PubMed]

138. Herlin, G.; Kolbeck, K.G.; Menzel, P.L.; Svensson, L.; Aspelin, P.; Capitanio, A.; Axelsson, R. Quantitative assessment of ${ }^{99 \mathrm{~m}} \mathrm{Tc}$-depreotide uptake in patients with non-small-cell lung cancer: Immunohistochemical correlations. Acta Radiol. 2009, 50, 902-908. [CrossRef] [PubMed]

139. Hu, C.; Yi, C.; Hao, Z.; Cao, S.; Li, H.; Shao, X.; Zhang, J.; Qiao, T.; Fan, D. The effect of somatostatin and sstr3 on proliferation and apoptosis of gastric cancer cells. Cancer Biol. Ther. 2004, 3, 726-730. [CrossRef] [PubMed]

140. Mazzucchelli, R.; Morichetti, D.; Santinelli, A.; Scarpelli, M.; Bono, A.V.; Lopez-Beltran, A.; Cheng, L.; Montironi, R. Immunohistochemical expression and localization of somatostatin receptor subtypes in androgen ablated prostate cancer. Anal. Cell. Pathol. 2010, 33, 27-36. [CrossRef]

141. Sclafani, F.; Carnaghi, C.; Di Tommaso, L.; Rodari, M.; Destro, A.; Rimassa, L.; Giordano, L.; Chiti, A.; Roncalli, M.; Santoro, A. Detection of somatostatin receptor subtypes 2 and 5 by somatostatin receptor scintigraphy and immunohistochemistry: Clinical implications in the diagnostic and therapeutic management of gastroenteropancreatic neuroendocrine tumors. Tumori 2011, 97, 620-628. [PubMed]

142. Ji, X.Q.; Ruan, X.J.; Chen, H.; Chen, G.; Li, S.Y.; Yu, B. Somatostatin analogues in advanced hepatocellular carcinoma: An updated systematic review and meta-analysis of randomized controlled trials. Med. Sci. Monit. 2011, 17, RA169-RA176. [CrossRef] [PubMed]

143. Krenning, E.P.; Kwekkeboom, D.J.; Bakker, W.H.; Breeman, W.A.; Kooij, P.P.; Oei, H.Y.; van Hagen, M.; Postema, P.T.; de Jong, M.; Reubi, J.C.; et al. Somatostatin receptor scintigraphy with [ ${ }^{111}$ In-DTPA-D-Phe ${ }^{1}$ ]and [123I-Tyr ${ }^{3}$ ]-octreotide: The rotterdam experience with more than 1000 patients. Eur. J. Nuclear Med. 1993, 20, 716-731. [CrossRef]

144. Krenning, E.P.; Kwekkeboom, D.J.; Reubi, J.C.; Van Hagen, P.M.; van Eijck, C.H.; Oei, H.Y.; Lamberts, S.W. ${ }^{111}$ In-octreotide scintigraphy in oncology. Metab. Clin. Exp. 1992, 41, 83-86. [CrossRef]

145. De Jong, M.; Breeman, W.A.; Kwekkeboom, D.J.; Valkema, R.; Krenning, E.P. Tumor imaging and therapy using radiolabeled somatostatin analogues. Acc. Chem. Res. 2009, 42, 873-880. [CrossRef] [PubMed]

146. Menda, Y.; Kahn, D. Somatostatin receptor imaging of non-small cell lung cancer with ${ }^{99 \mathrm{~m}} \mathrm{Tc}$ depreotide. Semin. Nucl. Med. 2002, 32, 92-96. [CrossRef] [PubMed]

147. Gabriel, M.; Decristoforo, C.; Donnemiller, E.; Ulmer, H.; Watfah Rychlinski, C.; Mather, S.J.; Moncayo, R. An intrapatient comparison of ${ }^{99 \mathrm{~m}}$ Tc-EDDA/HYNIC-TOC with ${ }^{111} \mathrm{In}$-DTPA-octreotide for diagnosis of somatostatin receptor-expressing tumors. J. Nucl. Med. 2003, 44, 708-716. [PubMed] 
148. Sun, L.C.; Coy, D.H. Somatostatin receptor-targeted anti-cancer therapy. Curr. Drug Deliv. 2011, 8, 2-10. [CrossRef] [PubMed]

149. Sun, L.; Fuselier, J.A.; Coy, D.H. Effects of camptothecin conjugated to a somatostatin analog vector on growth of tumor cell lines in culture and related tumors in rodents. Drug Deliv. 2004, 11, 231-238. [CrossRef] [PubMed]

150. Sun, L.C.; Luo, J.; Mackey, L.V.; Fuselier, J.A.; Coy, D.H. A conjugate of camptothecin and a somatostatin analog against prostate cancer cell invasion via a possible signaling pathway involving PI3K/AKT, $\alpha \mathrm{v} \beta 3 / \alpha \mathrm{v} \beta 5$ and MMP-2/-9. Cancer Lett. 2007, 246, 157-166. [CrossRef] [PubMed]

151. Sun, L.C.; Mackey, L.V.; Luo, J.; Fuselier, J.A.; Coy, D.H. Targeted chemotherapy using a cytotoxic somatostatin conjugate to inhibit tumor growth and metastasis in nude mice. Clin. Med. Oncol. 2008, 2, 491-499. [PubMed]

152. Huang, C.-M.; Wu, Y.-T.; Chen, S.-T. Targeting delivery of paclitaxel into tumor cells via somatostatin receptor endocytosis. Chem. Biol. 2000, 7, 453-461. [CrossRef]

153. Engel, J.B.; Schally, A.V.; Dietl, J.; Rieger, L.; Hönig, A. Targeted therapy of breast and gynecological cancers with cytotoxic analogues of peptide hormones. Mol. Pharm. 2007, 4, 652-658. [CrossRef] [PubMed]

154. Schally, A.V.; Nagy, A. Cancer chemotherapy based on targeting of cytotoxic peptide conjugates to their receptors on tumors. Eur. J. Endocrinol. 1999, 141, 1-14. [CrossRef] [PubMed]

155. Engel, J.B.; Schally, A.V.; Halmos, G.; Baker, B.; Nagy, A.; Keller, G. Targeted cytotoxic bombesin analog AN-215 effectively inhibits experimental human breast cancers with a low induction of multi-drug resistance proteins. Endocr. Relat. Cancer 2005, 12, 999-1009. [CrossRef] [PubMed]

156. Lambert, J.M. Drug-conjugated monoclonal antibodies for the treatment of cancer. Curr. Opin. Pharmacol. 2005, 5, 543-549. [CrossRef] [PubMed]

157. Alley, S.C.; Okeley, N.M.; Senter, P.D. Antibody-drug conjugates: Targeted drug delivery for cancer. Curr. Opin. Chem. Biol. 2010, 14, 529-537. [CrossRef] [PubMed]

158. Govindan, S.V.; Goldenberg, D.M. Designing immunoconjugates for cancer therapy. Expert Opin. Biol. Ther. 2012, 12, 873-890. [CrossRef] [PubMed]

159. Casi, G.; Neri, D. Antibody-drug conjugates: Basic concepts, examples and future perspectives. J. Control. Release 2012, 161, 422-428. [CrossRef] [PubMed]

160. Teicher, B.A. Antibody-drug conjugate targets. Curr. Cancer Drug Targets 2009, 9, 982-1004. [CrossRef] [PubMed]

161. Redko, B.; Ragozin, E.; Andreii, B.; Helena, T.; Amnon, A.; Talia, S.Z.; Mor, O.-H.; Genady, K.; Gary, G. Synthesis, drug release, and biological evaluation of new anticancer drug-bioconjugates containing somatostatin backbone cyclic analog as a targeting moiety. Pept. Sci. 2015, 104, 743-752. [CrossRef] [PubMed]

162. Kostenich, G.; Livnah, N.; Bonasera, T.A.; Yechezkel, T.; Salitra, Y.; Litman, P.; Kimel, S.; Orenstein, A. Targeting small-cell lung cancer with novel fluorescent analogs of somatostatin. Lung Cancer 2005, 50, 319-328. [CrossRef] [PubMed]

163. Reubi, J.C.; Wenger, S.; Schmuckli-Maurer, J.; Schaer, J.-C.; Gugger, M. Bombesin receptor subtypes in human cancers: Detection with the universal radioligand ${ }^{125} \mathrm{I}-\left[\mathrm{D}-\mathrm{Tyr}^{6}, \beta-\mathrm{Ala}^{11}, \mathrm{Phe}^{13}, \mathrm{Nle}^{14}\right]$ bombesin(6-14). Clin. Cancer Res. 2002, 8, 1139-1146. [PubMed]

164. Jensen, R.T.; Battey, J.F.; Spindel, E.R.; Benya, R.V. International union of pharmacology. LXVIII. Mammalian bombesin receptors: Nomenclature, distribution, pharmacology, signaling, and functions in normal and disease states. Pharmacol. Rev. 2008, 60,1-42. [CrossRef] [PubMed]

165. Cuttitta, F.; Carney, D.N.; Mulshine, J.; Moody, T.W.; Fedorko, J.; Fischler, A.; Minna, J.D. Bombesin-like peptides can function as autocrine growth factors in human small-cell lung cancer. Nature 1985, 316, 823-826. [CrossRef] [PubMed]

166. Moody, T.W.; Pert, C.B.; Gazdar, A.F.; Carney, D.N.; Minna, J.D. High levels of intracellular bombesin characterize human small-cell lung carcinoma. Science 1981, 214, 1246-1248. [CrossRef] [PubMed]

167. Moody, T.W.; Carney, D.N.; Cuttitta, F.; Quattrocchi, K.; Minna, J.D.I. High affinity receptors for bombesin/GRP-like peptides on human small cell lung cancer. Life Sci. 1985, 37, 105-113. [CrossRef] 
168. Moody, T.W.; Sun, L.C.; Mantey, S.A.; Pradhan, T.; Mackey, L.V.; Gonzales, N.; Fuselier, J.A.; Coy, D.H.; Jensen, R.T. In vitro and in vivo antitumor effects of cytotoxic camptothecin-bombesin conjugates are mediated by specific interaction with cellular bombesin receptors. J. Pharmacol. Exp. Ther. 2006, 318, 1265-1272. [CrossRef] [PubMed]

169. Safavy, A.; Raisch, K.P.; Matusiak, D.; Bhatnagar, S.; Helson, L. Single-drug multiligand conjugates: Synthesis and preliminary cytotoxicity evaluation of a paclitaxel-dipeptide "scorpion" molecule. Bioconj. Chem. 2006, 17, 565-570. [CrossRef] [PubMed]

170. Nagy, A.; Armatis, P.; Cai, R.-Z.; Szepeshazi, K.; Halmos, G.; Schally, A.V. Design, synthesis, and in vitro evaluation of cytotoxic analogs of bombesin-like peptides containing doxorubicin or its intensely potent derivative, 2-pyrrolinodoxorubicin. Proc. Natl. Acad. Sci. USA 1997, 94, 652-656. [CrossRef] [PubMed]

171. Moody, T.W.; Pradhan, T.; Mantey, S.A.; Jensen, R.T.; Dyba, M.; Moody, D.; Tarasova, N.I.; Michejda, C.J. Bombesin marine toxin conjugates inhibit the growth of lung cancer cells. Life Sci. 2008, 82, 855-861. [CrossRef] [PubMed]

172. Cai, H.; Yang, H.; Xiang, B.; Li, S.; Liu, S.; Wan, L.; Zhang, J.; Li, Y.; Cheng, J.; Lu, X. Selective apoptotic killing of solid and hematologic tumor cells by bombesin-targeted delivery of mitochondria-disrupting peptides. Mol. Pharm. 2010, 7, 586-596. [CrossRef] [PubMed]

173. Cescato, R.; Maina, T.; Nock, B.; Nikolopoulou, A.; Charalambidis, D.; Piccand, V.; Reubi, J.C. Bombesin receptor antagonists may be preferable to agonists for tumor targeting. J. Nucl. Med. 2008, 49, 318-326. [CrossRef] [PubMed]

174. Mansi, R.; Fleischmann, A.; Macke, H.R.; Reubi, J.C. Targeting grpr in urological cancers-from basic research to clinical application. Nat. Rev. Urol. 2013, 10, 235-244. [CrossRef] [PubMed]

175. Ramos-Alvarez, I.; Moreno, P.; Mantey, S.A.; Nakamura, T.; Nuche-Berenguer, B.; Moody, T.W.; Coy, D.H.; Jensen, R.T. Insights into bombesin receptors and ligands: Highlighting recent advances. Peptides 2015, 72, 128-144. [CrossRef] [PubMed]

176. Oller-Salvia, B.; Sánchez-Navarro, M.; Ciudad, S.; Guiu, M.; Arranz-Gibert, P.; Garcia, C.; Gomis, R.R.; Cecchelli, R.; García, J.; Giralt, E.; et al. Miniap-4: A venom-inspired peptidomimetic for brain delivery. Angew. Chem. Int. Ed. 2016, 55, 572-575. [CrossRef] [PubMed]

177. Kurzrock, R.; Gabrail, N.; Chandhasin, C.; Moulder, S.; Smith, C.; Brenner, A.; Sankhala, K.; Mita, A.; Elian, K.; Bouchard, D.; et al. Safety, pharmacokinetics, and activity of GRN1005, a novel conjugate of angiopep-2, a peptide facilitating brain penetration, and paclitaxel, in patients with advanced solid tumors. Mol. Cancer Ther. 2012, 11, 308-316. [CrossRef] [PubMed]

178. Drappatz, J.; Brenner, A.; Wong, E.T.; Eichler, A.; Schiff, D.; Groves, M.D.; Mikkelsen, T.; Rosenfeld, S.; Sarantopoulos, J.; Meyers, C.A.; et al. Phase I study of GRN1005 in recurrent malignant glioma. Clin. Cancer Res. 2013, 19, 1567-1576. [CrossRef] [PubMed]

179. Elamrawy, F.; Othman, A.A.; Adkins, C.; Helmy, A.; Nounou, M.I. Tailored nanocarriers and bioconjugates for combating glioblastoma and other brain tumors. J. Cancer Metastasis Treat. 2016, 2, 112-122. [CrossRef]

180. Che, C.; Yang, G.; Thiot, C.; Lacoste, M.C.; Currie, J.C.; Demeule, M.; Regina, A.; Beliveau, R.; Castaigne, J.P. New angiopep-modified doxorubicin (ANG1007) and etoposide (ANG1009) chemotherapeutics with increased brain penetration. J. Med. Chem. 2010, 53, 2814-2824. [CrossRef] [PubMed]

181. Regina, A.; Demeule, M.; Tripathy, S.; Lord-Dufour, S.; Currie, J.-C.; Iddir, M.; Annabi, B.; Castaigne, J.-P.; Lachowicz, J.E. ANG4043, a novel brain-penetrant peptide-mAb conjugate, is efficacious against HER2-positive intracranial tumors in mice. Mol. Cancer Ther. 2015, 14, 129-140. [CrossRef] [PubMed]

182. Thomas, F.C.; Taskar, K.; Rudraraju, V.; Goda, S.; Thorsheim, H.R.; Gaasch, J.A.; Mittapalli, R.K.; Palmieri, D.; Steeg, P.S.; Lockman, P.R.; et al. Uptake of ANG1005, a novel paclitaxel derivative, through the blood-brain barrier into brain and experimental brain metastases of breast cancer. Pharm. Res. 2009, 26, 2486-2494. [CrossRef] [PubMed]

183. Xin, H.; Jiang, X.; Gu, J.; Sha, X.; Chen, L.; Law, K.; Chen, Y.; Wang, X.; Jiang, Y.; Fang, X. Angiopep-conjugated poly(ethylene glycol)-co-poly(epsilon-caprolactone) nanoparticles as dual-targeting drug delivery system for brain glioma. Biomaterials 2011, 32, 4293-4305. [CrossRef] [PubMed]

184. Shen, J.; Zhan, C.; Xie, C.; Meng, Q.; Gu, B.; Li, C.; Zhang, Y.; Lu, W. Poly(ethylene glycol)-block-poly(D,L-lactide acid) micelles anchored with angiopep-2 for brain-targeting delivery. J. Drug Target. 2011, 19, 197-203. [CrossRef] [PubMed] 
185. Sun, X.; Pang, Z.; Ye, H.; Qiu, B.; Guo, L.; Li, J.; Ren, J.; Qian, Y.; Zhang, Q.; Chen, J.; et al. Co-delivery of pEGFP-hTRAIL and paclitaxel to brain glioma mediated by an angiopep-conjugated liposome. Biomaterials 2012, 33, 916-924. [PubMed]

186. Nagy, A.; Schally, A.V. Targeting cytotoxic conjugates of somatostatin, luteinizing hormone-releasing hormone and bombesin to cancers expressing their receptors: A "smarter" chemotherapy. Curr. Pharm. Des. 2005, 11, 1167-1180. [CrossRef] [PubMed]

187. Aggarwal, S.; Ndinguri, M.W.; Solipuram, R.; Wakamatsu, N.; Hammer, R.P.; Ingram, D.; Hansel, W. $\left[\mathrm{DLys}^{6}\right]$-luteinizing hormone releasing hormone-curcumin conjugate inhibits pancreatic cancer cell growth in vitro and in vivo. Int. J. Cancer 2011, 129, 1611-1623. [CrossRef] [PubMed]

188. Temming, K.; Schiffelers, R.M.; Molema, G.; Kok, R.J. RGD-based strategies for selective delivery of therapeutics and imaging agents to the tumour vasculature. Drug Res. Updates 2005, 8, 381-402. [CrossRef] [PubMed]

189. Danhier, F.; Breton, A.L.; Préat, V. RGD-based strategies to target alpha(v) beta(3) integrin in cancer therapy and diagnosis. Mol. Pharm. 2012, 9, 2961-2973. [CrossRef] [PubMed]

190. Wang, H.; Chen, K.; Cai, W.; Li, Z.; He, L.; Kashefi, A.; Chen, X. Integrin-targeted imaging and therapy with RGD4C-TNF fusion protein. Mol. Cancer Ther. 2008, 7, 1044-1053. [CrossRef] [PubMed]

191. De Groot, F.M.; Broxterman, H.J.; Adams, H.P.; van Vliet, A.; Tesser, G.I.; Elderkamp, Y.W.; Schraa, A.J.; Kok, R.J.; Molema, G.; Pinedo, H.M.; et al. Design, synthesis, and biological evaluation of a dual tumor-specific motive containing integrin-targeted plasmin-cleavable doxorubicin prodrug. Mol. Cancer Ther. 2002, 1, 901-911. [PubMed]

192. He, X.; Alves, C.S.; Oliveira, N.; Rodrigues, J.; Zhu, J.; Bányai, I.; Tomás, H.; Shi, X. RGD peptide-modified multifunctional dendrimer platform for drug encapsulation and targeted inhibition of cancer cells. Colloids Surf. B Biointerfaces 2015, 125, 82-89. [CrossRef] [PubMed]

193. Miura, Y.; Takenaka, T.; Toh, K.; Wu, S.; Nishihara, H.; Kano, M.R.; Ino, Y.; Nomoto, T.; Matsumoto, Y.; Koyama, H.; et al. Cyclic RGD-linked polymeric micelles for targeted delivery of platinum anticancer drugs to glioblastoma through the blood-brain tumor barrier. ACS Nano 2013, 7, 8583-8592. [CrossRef] [PubMed]

194. Murphy, E.A.; Majeti, B.K.; Barnes, L.A.; Makale, M.; Weis, S.M.; Lutu-Fuga, K.; Wrasidlo, W.; Cheresh, D.A. Nanoparticle-mediated drug delivery to tumor vasculature suppresses metastasis. Proc. Natl. Acad. Sci. USA 2008, 105, 9343-9348. [CrossRef] [PubMed]

195. Dal Pozzo, A.; Ni, M.-H.; Esposito, E.; Dallavalle, S.; Musso, L.; Bargiotti, A.; Pisano, C.; Vesci, L.; Bucci, F.; Castorina, M.; et al. Novel tumor-targeted rgd peptide-camptothecin conjugates: Synthesis and biological evaluation. Bioorg. Med. Chem. 2010, 18, 64-72. [CrossRef] [PubMed]

196. Zhan, C.; Gu, B.; Xie, C.; Li, J.; Liu, Y.; Lu, W. Cyclic rgd conjugated poly(ethylene glycol)-co-poly(lactic acid) micelle enhances paclitaxel anti-glioblastoma effect. J. Control. Release 2010, 143, 136-142. [CrossRef] [PubMed]

197. Eldar-Boock, A.; Miller, K.; Sanchis, J.; Lupu, R.; Vicent, M.J.; Satchi-Fainaro, R. Integrin-assisted drug delivery of nano-scaled polymer therapeutics bearing paclitaxel. Biomaterials 2011, 32, 3862-3874. [CrossRef] [PubMed]

198. Ryppa, C.; Mann-Steinberg, H.; Fichtner, I.; Weber, H.; Satchi-Fainaro, R.; Biniossek, M.L.; Kratz, F. In vitro and in vivo evaluation of doxorubicin conjugates with the divalent peptide E-[c(RGDfK $\left.)_{2}\right]$ that targets integrin $\alpha \mathrm{v} \beta 3$. Bioconj. Chem. 2008, 19, 1414-1422. [CrossRef] [PubMed]

199. Ryppa, C.; Mann-Steinberg, H.; Biniossek, M.L.; Satchi-Fainaro, R.; Kratz, F. In vitro and in vivo evaluation of a paclitaxel conjugate with the divalent peptide E-[c(RGDfK $\left.)_{2}\right]$ that targets integrin $\alpha v \beta 3$. Int. J. Pharm. 2009, 368, 89-97. [CrossRef] [PubMed]

200. Reubi, J.C. Peptide receptors as molecular targets for cancer diagnosis and therapy. Endocr. Rev. 2003, 24, 389-427. [CrossRef] [PubMed]

201. Nagy, A.; Schally, A.V.; Halmos, G.; Armatis, P.; Cai, R.-Z.; Csernus, V.; Kovács, M.; Koppán, M.; Szepesházi, K.; Kahán, Z. Synthesis and biological evaluation of cytotoxic analogs of somatostatin containing doxorubicin or its intensely potent derivative, 2-pyrrolinodoxorubicin. Proc. Natl. Acad. Sci. USA 1998, 95, 1794-1799. [CrossRef] [PubMed]

202. Radulovic, S.; Nagy, A.; Szoke, B.; Schally, A.V. Cytotoxic analog of somatostatin containing methotrexate inhibits growth of mia paca-2 human pancreatic cancer xenografts in nude mice. Cancer Lett. 1992, 62, 263-271. [CrossRef] 
203. Kiaris, H.; Schally, A.V.; Nagy, A.; Sun, B.; Armatis, P.; Szepeshazi, K. Targeted cytotoxic analogue of bombesin/gastrin-releasing peptide inhibits the growth of H-69 human small-cell lung carcinoma in nude mice. Br. J. Cancer 1999, 81, 966-971. [CrossRef] [PubMed]

204. Safavy, A.; Raisch, K.P.; Khazaeli, M.B.; Buchsbaum, D.J.; Bonner, J.A. Paclitaxel derivatives for targeted therapy of cancer: Toward the development of smart taxanes. J. Med. Chem. 1999, 42, 4919-4924. [CrossRef] [PubMed]

205. Hamilton, G.S. Antibody-drug conjugates for cancer therapy: The technological and regulatory challenges of developing drug-biologic hybrids. Biologicals 2015, 43, 318-332. [CrossRef] [PubMed]

206. Li, J.; Wang, Y.; Liang, R.; An, X.; Wang, K.; Shen, G.; Tu, Y.; Zhu, J.; Tao, J. Recent advances in targeted nanoparticles drug delivery to melanoma. Nanomed. Nanotechnol. Biol. Med. 2015, 11, 769-794. [CrossRef] [PubMed]

207. Raucher, D.; Ryu, J.S. Cell-penetrating peptides: Strategies for anticancer treatment. Trends Mol. Med. 2015, 21, 560-570. [CrossRef] [PubMed]

(C) 2016 by the authors; licensee MDPI, Basel, Switzerland. This article is an open access article distributed under the terms and conditions of the Creative Commons Attribution (CC-BY) license (http:/ / creativecommons.org/licenses/by/4.0/). 